\title{
1 A network of cytosolic (co)chaperones promotes the biogenesis of 2 mitochondrial signal-anchored outer membrane proteins
}

4 Layla Drwesh ${ }^{1}$, Benjamin Heim², Max Graf ${ }^{1}$, Linda $\mathrm{Kehr}^{1}$, Lea Hansen-Palmus ${ }^{1}$, Mirita Franz5 Wachtel $^{3}$, Boris Macek $^{3}$, Hubert Kalbacher ${ }^{1}$, Johannes Buchner ${ }^{2}$, and Doron Rapaport ${ }^{1, *}$

$7 \quad{ }^{1}$ Interfaculty Institute of Biochemistry, University of Tübingen, 72076 Tübingen, Germany

$8{ }^{2}$ Center for Integrated Protein Science, Department Chemie, Technische Universität München, 985748 Garching, Germany

$10{ }^{3}$ Proteome Center Tübingen, Interfaculty Institute for Cell Biology, University of Tübingen, 1172076 Tübingen, Germany

* To whom correspondence should be addressed: Tübingen, Germany.

Tel: +49-7071-2974184; E-mail: doron.rapaport@uni-tuebingen.de.

ORCID: 0000-0003-3136-1207

\section{Running title:}

21 Biogenesis of mitochondrial outer membrane proteins 
24 Signal-anchored (SA) proteins are anchored into the mitochondrial outer membrane (OM) via a single transmembrane segment at their $\mathrm{N}$-terminus while the bulk of the proteins is facing the cytosol. These proteins are encoded by nuclear DNA, translated on cytosolic ribosomes, and are then targeted to the organelle and inserted into its OM by import factors. Recently, research on the insertion mechanisms of these proteins into the mitochondrial OM have gained a lot of attention. In contrast, the early cytosolic steps of their biogenesis are unresolved. Using various proteins from this category and a broad set of in vivo, in organello, and in vitro assays, we reconstituted the early steps of their biogenesis. We identified a subset of molecular (co)chaperones that interact with newly synthesized SA proteins, namely, Hsp70 and Hsp90 chaperones and co-chaperones from the Hsp40 family like Ydj1 and Sis1. These interactions were mediated by the hydrophobic transmembrane segments of the SA proteins. We further demonstrate that interfering with these interactions inhibits the biogenesis of SA proteins to varying extents. Finally, we could demonstrate direct interaction of peptides corresponding to the transmembrane segments of SA proteins with the (co)chaperones and reconstitute in vitro the transfer of such peptides from the Hsp70 chaperone to the mitochondrial Tom70 receptor. Collectively, this study unravels an array of cytosolic chaperones and mitochondrial import factors that facilitates the targeting and membrane integration of mitochondrial SA proteins. 


\section{Introduction}

Even though mitochondria have their own genome, the vast majority of their proteins are encoded by the nuclear genome, synthesized on cytosolic ribosomes, and then imported into the organelle. The early stages of these pathways are believed to be mediated by cytosolic factors and chaperones, whereas the later ones are facilitated by protein import machineries that have evolved in the different mitochondrial compartments (Neupert and Herrmann, 2007; Wiedemann and Pfanner, 2017).

The mitochondrial outer membrane harbors proteins with variable topologies that can span the membrane once, twice, or as multi-span proteins. Proteins that span the membrane once can have their single transmembrane segment (TMS) in the center of the protein or at the $\mathrm{N}$ - or $\mathrm{C}$ terminus (Drwesh and Rapaport, 2020; Gupta\& Becker, 2021). The latter group is called the tail-anchored proteins whereas those anchored via an N-terminal segment are known as signalanchored (SA) proteins. Some known members of SA proteins are the TOM receptors Tom70 and Tom20, the quality control protein Msp1 (Okreglak and Walter, 2014; Chen et al., 2014), and the mitochondrial outer membrane isoform of Mcr1 (Mcr1mom) (Lamb et al., 1999).

Despite sharing similar protein topology, SA proteins do not appear to follow the same insertion route. While insertion of Tom 70 and Tom 20 was previously reported to be dependent on the MIM complex and elements of the TOM complex (Ahting et al., 2005; Becker et al., 2008; Popov-Čeleketić et al., 2008), Msp1 mitochondrial insertion was shown to require only the MIM complex. The biogenesis of another member of the group Mcr1mom, has been proposed to be independent of the TOM complex, although it is yet unclear whether the MIM complex is involved (Meineke et al., 2008; Vitali et al., 2020; Doan et al., 2020).

Like the rest of the mitochondrial OM proteins, SA proteins are initially synthesized in the cytosol before being targeted to mitochondria. Such proteins contain an exposed hydrophobic transmembrane segment, which makes them vulnerable to aberrant folding and aggregation. This situation can potentially result in cytotoxic protein species, which might contribute to the pathomechanism of various neurodegenerative and other diseases (Bohush et al., 2019: Chaari, 2019). Hence, it is widely thought that cytosolic factors bind such newly synthesized proteins, thereby maintaining their import-competent conformation by counteracting aggregation, degradation, and misfolding (Neupert and Pfanner, 1993). 
In the yeast Saccharomyces cerevisiae, a large repertoire of molecular chaperones was identified that regulate protein quality control. These elements are classified into different families according to their molecular masses and the way they interact with their substrate (Mokry et al., 2015). Chaperones from the Hsp100 family have high binding affinity to aggregated proteins and function as disaggregases by both reactivating and resolubilizing them (Zolkiewski et al., 2012). Chaperones from the Hsp70 family (like Ssa1-4 in yeast) function in a wide range of biological processes, such as modulating folding and preventing aggregation. Chaperones from this family associate with a broad spectrum of client proteins in an ATPregulated cycle. Client protein recognition is regulated mainly by J-proteins (co-chaperones like Ydj1 and Sis1 in yeast) from the Hsp40 family that stimulate ATP hydrolysis, thereby facilitating client capture by Hsp70 (Cry, 1995; Kampinga and Craig, 2010; Wyszkowski et al., 2021). Beside their crucial role in modulating the ATPase cycle of Hsp70 through their Jdomain, Hsp40 chaperones can also bind unfolded protein substrates (Johnson and Craig, 2001; Li et al., 2009). In addition, cells harbour small heat shock proteins (sHSPs) that bind nonnative proteins and are crucial for preventing irreversible aggregation processes. Such sHSPs were recently found to be involved also in protecting proteins from mechanical stress (Haslbeck et al., 2019; Collier and Benesch, 2020). In yeast, Hsp26 is a chaperone from this family that has been reported to associate with cytosolic aggregates allowing the Ssa1-Hsp104 chaperone system to efficiently disassemble and refold them (Haslbeck et al., 2005; Cashikar et al., 2005).

Chaperones of the Hsp70 family as well as some of their co-chaperones were implicated in the import of mitochondrial presequence-containing substrates (Hoseini et al., 2016; Xie et al., 2017; Endo et al., 1996; Deshaies et al., 1988; Caplan et al., 1992) and carrier proteins of the inner membrane (Young et al., 2003; Bhangoo et al., 2007). For example, the co-chaperone Djp1 plays a key role in the ER-SURF pathway which involves a de-tour of mitochondrial substrates to the ER (Hansen et al., 2018). Such (co)chaperones were also reported to facilitate the import of mitochondrial OM proteins like Mim1 or Tom22 (Papić et al., 2013; Opaliński et al., 2018). Furthermore, we previously reported that cytosolic Hsp70 and Hsp40 chaperones enable the biogenesis of mitochondrial $\beta$-barrel proteins (Jores et al., 2018). Pex19, which is a cytosolic chaperone associated with the peroxisomal import of membrane proteins, has also been found, along with Ssa1 and its co-chaperone Sti1, to assist the biogenesis of mitochondrial tail-anchored proteins namely, Fis1 and Gem1 (Cichocki et al., 2018) (Jansen and van der Klei, 2019). 
Despite this progress in our understanding of the contribution of cytosolic chaperones to mitochondrial biogenesis, no cytosolic factors have been reported so far as mediators of the biogenesis of mitochondrial SA proteins. Currently, there is scarce information regarding the early cytosolic events that assure their safe passage through the cytosol. To fill this gap, we have employed a combined experimental strategy consisting of assays with yeast cells extract, isolated organelles, and in vitro experiments with purified proteins. We could identify a subset of Hsp70 and Hsp40 (co)chaperones that interacts with SA proteins. These (co)chaperones were further shown to be crucial for the mitochondrial import of SA proteins. Furthermore, we suggest a novel role of the import receptors Tom70 in promoting the insertion of SA proteins by serving as a docking site for the Hsp70 chaperone.

\section{Results}

\section{Cytosolic chaperones interact with newly synthesized signal-anchored proteins}

Signal-anchored proteins are, due to their hydrophobic segments, at a high risk of aggregation and misfolding following their translation in the cytosol. We aimed to search for factors that can prevent such a scenario and maintain the SA substrates in an import-competent conformation. We chose four SA model proteins to study the potential involvement of such cytosolic components: the two receptor subunits of the TOM complex, Tom 20 and Tom70, and two additional proteins namely, Msp1 and the OM isoform of Mcr1 (Mcr1mom). Initially, we wanted to determine which factors can interact with newly synthesized SA proteins. To this end, we used yeast extract to translate in vitro signal-anchored proteins with a C-terminally HA-tag. Since the yeast extract does not contain organelles to where the freshly translated proteins can be targeted, we anticipated that such SA proteins should associate in the hydrophilic environment of the extract with factors, which will maintain them in an importcompetent conformation. The tail-anchored protein Fis1 and the $\beta$-barrel protein Porin were included for comparison and the unrelated protein dihydrofolate reductase (DHFR) was used as a control. After their synthesis, all proteins were pulled down with anti-HA beads and copurified proteins in the elution fraction were analyzed by western blot followed by immunodecoration with antibodies against different cytosolic elements (Fig. 1A, B).

All four signal-anchored proteins co-eluted with the Hsp70 chaperones Ssa1/2, and the Hsp40 co-chaperones Ydj1, Sis1 and Djp1. Weaker interactions were observed with the Hsp90 
chaperones Hsc82/Hsp82 and their co-chaperones Aha1 and Sti1. The eluates contained also Hsp104 chaperone and minor amounts of Hsp42 chaperone, suggesting that minor portion of the newly synthesized proteins got aggregated. The co-chaperone Hch1 and the cytosolic protein Bmh1 were not co-eluted with any of the tested proteins (Fig. 1A, B). Control elution fraction containing newly synthesized DHFR had neglectable amounts of co-purified (co)chaperones, indicating the binding specificity of chaperone-substrate. As we observed previously (Jores et al., 2018), the $\beta$-barrel protein Porin also associated with the various (co)chaperones.

To validate the western blot results and to search for additional (co)chaperones co-purified with the newly translated SA proteins, the elution fractions from such pull-down assays were analyzed also by mass spectrometry. The mass spectrometry analysis of the eluates from pulldowns with Msp1, Mcr1, or (as a control) with mock pull-down where no mRNA was added to the lysate are shown in Table S1. Several chaperones, which are not included in the western blot due to lack of antibodies, were additionally detected in the eluate of both proteins Msp1 and Mcrl. The detected proteins are presented in two groups. The first contained those proteins that were not found at all in the mock eluate, hence their enrichment ratio in Msp1 and Mcr1 eluates could not be calculated (Table S1A). Among these were chaperones from the Hsp70 family namely, Ssa4, Snl1 and Lhs1. The second group is the set of proteins that were found in minor amounts also in the mock elution, and thus their relative enrichment as compared to the mock pull-down could be determined (Table S1B). Amongst them, the Hsp70 chaperones Ssc1, Sse 1 and Ssb1/2, in addition to the ribosome associated complex (RAC) chaperone Zuo1 were detected. Taken together, the combined analysis of the pull-down assays shows multifaceted interactions between newly synthesized SA proteins and cytosolic chaperones and co-chaperones.

\section{The hydrophobic transmembrane domain of SA proteins mediates their interactions with cytosolic (co)chaperones}

The detected interactions of a subset of cytosolic (co)chaperones with SA proteins led us to ask which part of these latter proteins mediate such association. A likely candidate for this task is the proteins' hydrophobic TMS. To test this assumption, we constructed two additional Cterminally HA-tagged versions of each SA protein - one construct encodes the cytosolic part of the protein (indicated by protein name-C, Fig. 2) and the second encodes only the hydrophobic TMS (indicated by protein name-T, Fig. 2). These two constructs together with 
the full-length (FL) version were used for in vitro translation in yeast extract followed by pulldown assay. As expected for small proteins, all three constructs encoding the hydrophobic TMSs were synthesized to a lower extent as compared to the constructs representing the cytosolic moieties or the full-length proteins (Fig. 2, input panels). Yet, similar levels of bound (co)chaperones were observed in the eluates of the hydrophobic TMSs and the full-length versions (Fig. 2A-C). In contrast, only marginal binding of (co)chaperones to the soluble cytosolic parts of the SA proteins or to the control protein DHFR was detected (Fig. 2A-C). Taken together, our findings suggest that the interactions between SA proteins and molecular chaperones are mainly governed by the TMSs of the mitochondrial proteins.

\section{Signal-anchored proteins show variable dependence on Hsp40 co-chaperones}

After demonstrating that Hsp40 co-chaperones like Ydj1 and Sis1 can physically interact with newly synthesized SA proteins, we wanted to test if these interactions are relevant to the biogenesis of the latter group. These two co-chaperones were previously reported to be involved in the biogenesis of the $\beta$-barrel protein Porin (Jores et al., 2018). Moreover, Ydj1 has been implicated in the mitochondrial import of presequence-containing proteins (Caplan et al., 1992; Xie et al., 2017). To gain insight into the physiological relevance of these co-chaperones for the biogenesis of signal-anchored proteins, we created strains expressing YDJ1, SIS1 or both genes under the control of a tetracycline-repressible promoter. To accelerate the depletion process, ubiquitin was fused N-terminally to the down-regulated protein. To monitor the effect of depleted chaperones over time, cells were grown for two hours in the absence of doxycycline. Then, down-regulation was induced by supplementing doxycycline (Dox) to the medium, cells were harvested immediately (time $=0$ ) or after 1, 2 or 4 hours, and cytosolic and mitochondrial fractions were obtained. For comparison, cells were grown in the absence of doxycycline and harvested as well.

As anticipated, cytosolic levels of Ydj1 and Sis1 were gradually decreased over time after addition of doxycycline, whereas levels of other chaperones like Hsp104 and Hsp26 were not changed, demonstrating doxycycline's selectivity in suppressing the expression of only the genes regulated by the tetracycline promoter (Fig. 3A, C). Inspecting the mitochondrial fractions revealed that none of the inspected mitochondrial proteins was altered in Ydj1 depleted cells. In contrast, mitochondrial levels of Tom20 and Tom70 in Sis 1 depleted cells were moderately reduced after 4 hours, while no change was detected in the levels of the other signal-anchored proteins Msp1 and Mcr1, or other outer membrane proteins like Porin or Fis1 
(Fig. 3A-B). These findings might be explained by previous observations that the J-domain of Sis 1 can compensate for the loss of Ydj1 J-domain but not the other way around (Yan and Craig, 1999).

To avoid such cross compensation of the two co-chaperones, we wanted next to check the effect of the parallel depletion of both on the biogenesis of SA proteins. Interestingly, the levels of Tom 20 and Tom 70 were gradually reduced over time down to $40-50 \%$ of their levels in control conditions while levels of Msp1 and Mcr1 were not altered. As expected from our previous study (Jores et al., 2018), Porin also showed a decrease to 40\% (Fig. 3C-D). Altogether, these results suggest that biogenesis of various SA proteins rely to a different degree on Hsp40 cochaperones.

The highly reduced steady-state levels of Tom20 and Tom70 upon depletion of both cochaperones led us to conduct in vitro import assays. In these experiments we translated radiolabeled variants of Tom 20 and Tom70 in yeast extract from either control or Ydj1 and Sis1 depleted cells and incubated the newly synthesized proteins with isolated mitochondria. We found that extract depleted of both co-chaperones can support to a lower extent the import of Tom20 but to a normal level that of Tom70 (Fig. 4A, B). Thus, it seems that the import of Tom70 under these in vitro conditions can be compensated by other, yet unknown, factors.

\section{Depletion of Ydj1 and Sis1 can increase the risk for aggregation of newly synthesized} proteins

To better understand the involvement of Ydj1 and Sis1 in the cytosolic maintenance of signalanchored proteins, we aimed to analyze the interaction pattern between the other chaperones and the newly synthesized SA proteins in yeast cells depleted of Ydj1 and Sis1. We chose to utilize a strain that is depleted of both co-chaperones since their mutual function allows them to compensate for each other's loss. To this end, we translated HA-tagged variants of the four signal-anchored proteins in extract of either WT or Ydj1 and Sis1 depleted cells (YS $\downarrow$ ) and then performed pull down with anti-HA beads. Interestingly, we found that the interaction between the newly synthesized proteins and some of the chaperones was altered in cells depleted for both co-chaperones while other chaperones did not show any significant change. The co-purified levels of Hsp104 and Hsp26 chaperones were increased in the eluates of all SA proteins translated in the extract of the depletion strain (Fig. 5A, B). Both Hsp104 and Hsp26 are involved in disaggregation of substrate proteins. Hence the co-purification, in the absence of Sis1 and Ydj1, of these chaperones with newly synthesized SA proteins suggests 
that the cytosol of cells with highly reduced levels of these co-chaperones can offer less stabilization for the newly synthesized substrates and hence these substrates are more prone to aggregation under these conditions. These findings indicate a role of the Hsp40 co-chaperones in keeping the signal-anchored proteins stable in the cytosol.

\section{The binding affinity of substrate to Hsp70 chaperone Ssa1 is higher than the affinity to the co-chaperone Sis1}

To better understand the dynamics of chaperone-substrate interactions, we next aimed to investigate their binding kinetics and affinity using fluorescence anisotropy. Since we have shown that the interaction between chaperones and signal-anchored proteins is mediated by their transmembrane domain (Fig. 2), we synthesized peptides corresponding to residues 1-34 of Mcr1 and Tom70, which contain the TMS, and modified the peptides with the fluorescent dye Tetramethylrhodamine (TAMRA). Then, we monitored the anisotropy changes of these fluorescently labeled peptides upon their interaction with recombinantly expressed purified (co)chaperones. The fluorescence anisotropy of the TAMRA-labeled Tom70 and Mcr1 peptides increased upon addition of recombinant Ssal indicating the formation of a peptideSsal complex. As a control, such an increase was not observed when BSA was added, underlining the specificity of the chaperone-substrate interaction (Fig. 6A, B). These observations demonstrate that transmembrane segments of SA proteins can bind directly to Ssa1.

Next, we implemented a titration assay in which increasing concentrations of Ssa1 (Fig. 6 C, D) or Sis1 (Fig. 6 E, F) were sequentially added to either Tom70 or Mcr1 peptides. This approach enabled us to monitor the binding parameters and compare the binding affinity between substrate and different (co)chaperones. Based on these experiments, dissociation constants $(\mathrm{Kd})$ were determined according to hyperbolic regression curves fitted to the data. These Kds were calculated to be $2.42 \mu \mathrm{M}$ for Ssa1-Tom70(TMS) complex and 3.27 $\mu \mathrm{M}$ for Ssa1-Mcr1(TMS) complex (Fig. 6C, D). Interestingly, dissociation constants (Kd) of $18.3 \mu \mathrm{M}$ and $25.75 \mu \mathrm{M}$ were measured for Sis1-Tom70(TMS) complex and Sis1-Mcr1(TMS) complex, respectively (Fig. 6E, F). Collectively, these results show that the affinity between the substrates and the Hsp70 chaperone Ssa1 is several folds higher than their affinity to the cochaperone, Sis1. This observation supports the notion that the co-chaperone facilitates the initial low-affinity interaction with the substrate before transferring it to the main chaperone that has a higher affinity to the substrate. 


\section{Hsp70 chaperones are required for optimal biogenesis of SA proteins}

263

Hsp70 chaperones cooperate with different cofactors and are known to be regulated mainly by J-protein co-chaperones like Ydj1 and Sis1. Our results so far have shown that these chaperones play an important role in the biogenesis of SA proteins. To substantiate this assumption, we wished to examine whether inhibiting this chaperone can interfere with the import of SA proteins. Thus, we performed in vitro import assays in which the yeast extract used for protein translation was supplemented with the Hsp70 inhibitor, CBag (C-terminal Bag domain of human Bag-1M) prior to import into mitochondria (Jores et al., 2018). As a result, the import efficiency of both, Msp1 and Mcr1 decreased to 50\% and 20\% respectively, as compared to control BSA-supplemented yeast extract (Fig. 7 A, B). We previously observed that this inhibitor does not cause a general damage to the import capacity of mitochondria as it did not affect the import of the matrix-destined protein pSu9-DHFR (Jores et al., 2018). Altogether, these experiments suggest a crucial role for Hsp70 in facilitating proper insertion of SA proteins into the mitochondrial OM.

Considering the physiological relevance of both Hsp70 and Hsp40 (co)chaperones for the biogenesis of SA proteins, we aimed to understand the dynamics of the complex formation between the SA substrate, the Hsp40 co-chaperones (Sis1), and the Hsp70 chaperones (Ssa1). To this end, we performed additional set of fluorescence anisotropy experiments in which Ssa1, ATP and Sis1, each a few minutes apart and in a different order, were added to the Mcr1TAMRA-labeled peptide (Fig. 7 C-E). Since Ssa1 has ATPase activity that is modulated by Hsp40 co-chaperones, we tested whether the binding of Hsp40 or Hsp70 to the substrate is ATP-dependent. Higher anisotropy values were observed when Ssa1 was supplemented first, indicating complex formation between Ssa1-Mcr1 peptide. After adding ATP, the anisotropy was reduced indicating that the complex started to disassociate as a result of ADP exchange for ATP, which promotes chaperone-substrate release. However, addition of Sis 1 increased the anisotropy again suggesting either a complex formation between Sis 1 and the substrate or that Sis1 restored the complex formation between Ssa1 to Mcr1 peptide by tuning the ATPasedriven chaperone cycle of Ssa1 (Fig. 7C).

In another experiment we first added Sis1 to the Mcr1 peptide and, as expected, complex formation was observed (Fig. 7D). Only a slight decrease in the anisotropy was detected once Ssal was added to the mixture. This behaviour could be attributed to a transfer of the substrate from Sis 1 to Ssa1 due to higher affinity of the substrate of the latter protein. Interestingly, when 
ATP was supplied to the mixture at last, no further decrease in the anisotropy was measured (Fig. 7D). This lack of effect could be explained by one of the two possibilities - (i) since there is still Sis1 in the mixture, following the Ssa1-substrate disassociation due to ATP, the substrate re-associated with Sis1, or (ii) due to the presence of Sis1, the ATP hydrolysis is accelerated which retains Hsp70 chaperone conformation in favor of substrate binding, making the Ssa1substrate complex no longer sensitive to ATP.

In the last experiment, Sis 1 was supplemented after Ssa1 and an additional increase in anisotropy was observed (Fig. 7E). Since the total change in anisotropy is even larger than the increase observed in the presence of either Ssa1 or Sis 1 alone, this observation might suggest the formation of a ternary complex composed of Ssa1-Sis1-substrate. Importantly, this rise was not long-lasting, and the complex appears to dissociate over time (Fig. 7E). As before, the addition of ATP at this stage did not change the levels of anisotropy. Overall, these findings support a complex formation between Hsp70 and its SA substrate. In addition, they suggest a regulatory effect of ATP on this complex, which is no longer observed when Sis 1 is in the mixture, suggesting a role of Sis1 in stabilizing this complex.

\section{Tom20 and Tom70 receptors might play an offsetting role in the biogenesis of the SA proteins Msp1 and Mcr1}

Next, we wanted to decipher the late cytosolic events involving the recognition of newly synthesized proteins at the mitochondrial surface. To that goal we investigated, using different approaches, the potential involvement of the canonical import receptors Tom 20 and Tom70 in the biogenesis of Mcr1 or Msp1. First, we performed in vitro pull-down assays using the cytosolic domains of either Tom 20 or Tom $70 \mathrm{~N}$-terminally fused to a GST moiety. GST alone was included as a negative control. These GST-fusion proteins were incubated with freshly translated HA-tagged variants of Msp1, Mcr1 or DHFR (as a control). Following two hours of incubation in the presence of ATP to allow the release of potentially bound chaperones, the elution fraction was collected, and bound proteins were detected using anti-HA antibody. Msp1 and Mcrl displayed variable degrees of interaction with both receptors. After normalizing for the background binding to GST, Mcrl exhibited four times higher binding to the cytosolic domain of Tom 20 compared to that of Tom70, while Msp1 interacted with both almost equally. Of note, no binding was detected when DHFR was incubated with the receptors, demonstrating the specificity of the assay (Fig. 8A). 
Since prior to their incubation with the receptors, the SA proteins were translated in yeast extract containing the repertoire of molecular chaperones, we asked whether chaperones can be involved in the recognition process of the newly synthesized proteins by the receptors. Hence, we aimed to examine the potential interaction between the TOM receptors and different chaperones using the same approach namely, pull-down from yeast extract. Notably, Ydj1 showed similar binding levels to both receptors while Ssa1/2, Sti1 and Hsp104 exhibited stronger binding to the cytosolic domain of Tom70. On the other hand, Aha1 displayed a very strong interaction with the Tom 20 receptor. Other chaperones, like Hsp26 and Hch1 did not bind to either receptor (Fig. S1A).

Since the cooperation between the Hsp70 chaperone and Tom70/Tom20 receptors in facilitating productive delivery of a subset of preproteins to the receptor for subsequent membrane translocation has been reported in multiple publications (Mills et al., 2009; Fan et al., 2010; Fan et al., 2011; Komiya et al., 1997; Young et al., 2003, Wegele et al., 2006), we decided to further investigate the implications of such interactions for the biogenesis of SA proteins. Given that Tom70 contains a docking site for Hsp70s and Hsp90 chaperones, along with our observation that Ssa1/2 is probably involved in the insertion process of Msp1 and Mcr1, we asked whether the Tom70 receptor recognizes the polypeptide substrate while in complex with Ssa1 and whether Hsp70 docking is required for the formation of a productive substrate/Tom70 complex. For this purpose, we analyzed Mcr1 peptide binding to the GSTTom70 receptor in the presence of Ssa1, Sis1 and ATP supplemented in different orders and monitored the change in the anisotropy. As in other experiments (Fig. 7C), we observed complex formation after adding Ssal to Mcr1-peptide, which was detached upon ATP addition (Fig. 8B). However, once GST-Tom70 was added, a complex that caused an even higher anisotropy shift was formed (Fig. 8B), suggesting that Mcr1 peptide, after being released from Ssa1, formed a complex with Tom70 with higher affinity. Interestingly, a complex between Mcr1-peptide and Tom70, as indicated by a large increase in the measured anisotropy, was also formed when GST-Tom70 was supplemented first while Ssa1 was absent (Fig. 8C). Once Ssa1 and ATP were supplemented to this Tom70-Mcr1(TMS) complex, only a slight reduction shift was observed (Fig. $8 \mathrm{C}$ ), suggesting that the complex between Mcr1 substrate and Tom70 receptor remained mostly stable. This observation supports the assumption that the substrate interacts with the receptor with higher binding affinity than with the chaperone. Such an increased affinity can promote transfer of the substrate from the chaperone to the receptor. 
To test if the substrate-receptor interaction can occur even when the substrate is compounded with the Ssal chaperone, we enabled substrate-chaperone complex formation by supplementing Ssal first, followed by the addition of GST-Tom70. Surprisingly, a higher anisotropy shift was detected right after addition of GST-Tom70, indicating that the Tom70 receptor can bind the substrate while the latter is in complex with the chaperone. Addition of ATP, which aids the release of the substrate from the chaperone, resulted in an even higher increase in anisotropy (Fig. 8D), suggesting that the Tom70 receptor may bind the substrate with enhanced efficiency upon its release from the chaperone. To ensure that the receptor can indeed bind the substrate-chaperone complex, we stabilized the complex formed by Ssa1Mcr1(TMS) by co-addition of Sis1 to the mixture. Even in this case, the receptor Tom70 still interacted with the substrate (Fig. 8E). Overall, these findings suggest that SA substrate has a higher affinity for the receptor than for the chaperone. Furthermore, Tom70 is capable of binding substrates irrespective of the presence or absence of the Hsp70 chaperone Ssa1.

Having demonstrated that Tom 20 and Tom70 can bind newly translated SA proteins to a different degree (Fig. S1), we aimed to assess whether these interactions are required for their mitochondrial insertion. Previous studies have shown that the absence of either one of the TOM receptors does not cause a reduction in the mitochondrial steady state levels of Msp1 or Mcr1 (Vitali et al., 2020; Meineke et al., 2008). Nevertheless, since both receptors, Tom 20 and Tom70 can interact with Msp1 and Mcr1, we assume that when one receptor is deleted, the other one can compensate due to their partial overlapping function (Young et al., 2003). To test this hypothesis, we wanted to examine the direct effect of the loss of both receptors on the mitochondrial insertion of Msp1 and Mcr1. To this end, we conducted in vitro import assays of radiolabeled proteins (Msp1 and Mcr1) using two approaches. The first approach included mitochondria that had been trypsin-treated before import, and the second involved using mitochondria lacking the Tom 20 receptor (tom $20 \Delta$ strain) and treated with the C-terminal domain of human Hsp90 (C90) which is known to block the chaperone binding site on the mitochondrial import receptor Tom70, thus inhibiting its activity. Both Tom20 and Tom70 had their cytosolic domains degraded following trypsin treatment, and as a result, the import efficiency of Msp1 was decreased by 25\% (Fig. 9A). In line with a previous report (Meineke et al., 2008), the import efficiency of Mcr1 was not affected (Fig. 9B).

When WT mitochondria were treated with C90, which results in non-functional Tom70, import of Msp1 was reduced by 23\%. This seemingly contradicts a former study in which mitochondrial levels of Msp1 were not decreased in a Tom70 deleted strain (Vitali et al., 2020). 
However, this difference can be explained by the fact that in the previous study, the cells lacking Tom70 could adopt for the loss of Tom70, while the effect of inhibition by C90, on the other hand, is immediate and not reversible. Interestingly, insertion efficiency of Msp1 into mitochondria lacking Tom 20 was around 25\% higher as compared to control WT mitochondria (Fig. 9C, D), maybe because of the slightly elevated levels of Tom70 in these cells (Fig. S1B). Supporting this assumption, when the samples lacking Tom 20 were treated with C90, the membrane integration of Msp1 was reduced by 32\% (Fig. 9C). Similar results were obtained with Mcr (Fig. 9D). These findings substantiate the importance of Tom70 as a docking site for substrate SA proteins associated with (co)chaperones.

\section{Discussion}

The early cytosolic events in the biogenesis of mitochondrial outer membrane proteins are believed to involve cytosolic factors and chaperones to keep the newly synthesized proteins in an import-competent conformation, which is crucial for their effective membranal insertion. Such factors have been identified for some of the mitochondrial outer membrane proteins, such as the $\beta$-barrel proteins (Jores et al., 2018), and some single-span proteins (Cichocki et al., 2018; Papić et al., 2013; Opaliński et al., 2018). In this study, we employed four different model proteins from the SA family and identified several cytosolic chaperones that can interact with such newly synthesized proteins through their hydrophobic transmembrane domain. Of note, the cytosolic domains of these SA proteins were not associated with chaperones indicating that they are less prone to forming aggregates or to misfold in the cytosol. These observations are in line with the widely accepted concept that chaperones recognize mainly hydrophobic patches to bind their substrates (Li et al., 2009; Saio et al., 2014; Clerico et al., 2015).

We identify chaperones from the Hsp90, Hsp70, and Hsp40 families to interact with SA proteins. When we tested the role of the Hsp40 co-chaperones, Ydj1 and Sis1, which are two major J-domain proteins in the yeast cytosol, we observed that mitochondrial steady state levels of Tom 20 and Tom70 were largely reduced upon depletion of both chaperones and this effect was less pronounced when only one of the co-chaperones was depleted. This observation indicates, in agreement with an earlier study (Johnson and Craig, 2001), that Ydj1 and Sis1 share overlapping functions. In contrast, the steady-state levels of Msp1 and Mcr1, although they also interact with Ydj1 and Sis1, were unaffected by the co-depletion of the co- 
chaperones. This suggests that other Hsp40 co-chaperones most likely play a more central role in the biogenesis of these SA proteins. Furthermore, we could demonstrate that upon codepletion of both Ydj1 and Sis1, the newly synthesized SA proteins exhibited enhanced binding to Hsp26 and Hsp104 chaperones that are implicated in binding aggregated proteins (Zolkiewski et al., 2012; Zhou et al., 2011; Franzmann et al., 2005). These findings emphasize the involvement of Ydj1 and Sis1 in preventing cytotoxic protein aggregation and are in agreement with other proposed functions of both co-chaperones (Cry, 1995; Klaips et al., 2020).

Additionally, we have shown that both the in vitro import efficiency and the steady-state levels of Tom 20 are reduced upon depletion of Ydj1 and Sis1. In the case of Tom70, in vitro insertion was unaffected despite reduced mitochondrial steady state levels. These combined observations suggest that Ydj1 and Sis1 are involved in the biogenesis of SA proteins to varying degrees. The cis characteristics of the substrate proteins that dictate the variable dependency will be the topic of future studies.

We also validated via fluorescence anisotropy the interactions between a peptide corresponding to the transmembrane segment of Mcr1 and the two (co)chaperones Ssa1 and Sis1. Interestingly, the binding affinity of the substrate to the co-chaperone (Sis1) was 10-fold lower than the binding to the Hsp70 chaperone (Ssa1). These observations support the hypothesis that the substrate transfer from the co-chaperone to the main Hsp70 chaperones is driven by increased affinity to the latter. Similar results were also previously observed for a peptide representing the mitochondrial targeting element of the $\beta$-barrel protein Porin (Jores et al., 2018). According to our findings, the complex formed by Ssa1/substrate is regulated by the Jprotein Sis 1. Although we could show that a potential substrate is able to bind Hsp70 chaperone also in the absence of Sis1, this interaction was susceptible to ATP. In contrast, in the presence of Sis 1 the complex was no longer responsive to ATP, pointing out the regulatory function of Sis1 on the Hsp70 ATPase activity. In agreement with our findings, previous studies have shown that both Sis1 and Ydj1 facilitate binding between substrate and Hsp70 chaperone (Kampinga and Craig, 2010).

Our current findings show that inhibiting Ssa1 activity significantly reduces the integration of Msp1 and Mcr1 into the OM. This implies that in addition to its well-known function in facilitating protein folding, Ssa1 also directly supports the mitochondrial insertion of Msp1 and Mcr1. Of note, we could show that SA proteins can interact with the TOM receptor Tom70, 
suggesting that TOM receptors may play a role in recognizing newly synthesized SA proteins on the mitochondrial surface. At least for Mcr1, such a recognition by the import receptors might be related to the presence of an MTS-like stretch at residues 1-10 of the protein (Hahne et al., 1994). Furthermore, in accordance with previous observations (Backes et al., 2021; Kreimendahl and Rassow, 2020; Young et al., 2003), this recognition may involve an interplay between the Hsp70 chaperone and the Tom70 receptor. Based on our findings, we propose that the Ssa1/substrate complex is initially identified by Tom70 receptor, most likely using the docking site in Tom70, which may be crucial for correct targeting. The substrate is then released from the complex and relayed to Tom70 to which it has a higher affinity. These findings support the previously published study which proposed that the monomeric form of Tom70 is responsible for mediating initial chaperone docking and precursor recognition via its clamp domain followed by substrate release. This recognition is assumed to be facilitated by the exchange of ATP for ADP at the chaperone ATPase domain and results in the dimerization of Tom70 which favors interactions solely with the substrate (Mills et al., 2009).

When we analyzed the direct involvement of the TOM receptors in the biogenesis of Msp1 and Mcr1, we found that their insertion was reduced upon inhibition of Tom70 by C90. Surprisingly however, their insertion was enhanced upon Tom 20 deletion. This finding is in line with a previous study showing higher steady state levels of Msp1 in mitochondria devoid of Tom20 (Vitali et al., 2020). This enhancement could be attributed to higher expression of Tom70 to compensate for the deletion of Tom20. Moreover, inhibition of Tom70 in a deletion strain of Tom20 led to further reduction of the insertion of SA proteins, supporting the assumption that each receptor can compensate for the absence of the other one. Hence, it seems that both receptors might be involved in the biogenesis of the SA proteins Msp1 and Mcr1.

Altogether, our current findings, when combined with prior information, provide new insights into the cytosolic chain of events from the synthesis of SA proteins until their recognition at the mitochondrial surface. We propose that interactions between newly synthesized SA proteins and molecular chaperones are mediated by their hydrophobic patches. Such interactions are not only crucial for keeping the substrate protein in an import-competent conformation, but also for their proper mitochondrial targeting which involves the TOM complex receptors Tom 20 and Tom70. Although both receptors may not be vividly crucial for the actual membrane integration process, we propose that they are required for facilitating efficient delivery in the crowded environment of the cell. 
Materials and Methods

\section{Yeast strains and growth methods}

487 The parental strain YMK120 was used to create strains with genes under the control of a 488 tetracycline-repressible promoter (Gnanasundram and Koš, 2015). The tetracycline operator was inserted into the genome by homologous recombination using an insertion cassette amplified from the plasmids pMK632Kan and pMK632His (Gnanasundram and Koš, 2015). Strains with two genes under the control of the tetracycline operator were obtained by mating of strains with a single tet-regulated gene followed by tetrad dissection. Yeast strains expressing Ydj1 and Sis1 under tetracycline promotor were grown in YP-Sucrose medium (for mitochondria isolation) or in YPD medium (for isolation of cell extract). For mitochondria isolation, cells were grown for $2 \mathrm{~h}$ on medium lacking doxycycline before adding $2 \mu \mathrm{g} / \mathrm{ml}$ of doxycycline to the culture. Then, cells were cultured for different time periods before their harvest. All strains used in this study are listed in Table S2.

\section{Recombinant DNA techniques}

The plasmids pRS426-TPI-Tom20 and pRS426-TPI-Tom70 were used as templates for the PCR-amplification of the TOM20 and TOM70 genes, respectively. The amplification product was inserted into the plasmid pGEM4polyA-3HA using KpnI and BamHI restriction sites. The MSP1 gene was amplified by PCR from yeast genomic DNA with specific primers containing BamHI and HindIII restriction sites. The PCR product was cloned into the plasmid pGEM4 to obtain pGEM4-yk-Msp1 which was used as a template for cloning yk-Msp1 into pGEM4polyA-3HA plasmid using SacI and BamHI restriction sites. MCR1 gene was amplified by PCR using pGEM4-yk-Mcr1 plasmid as template. The amplification product was inserted into pGEM4polyA-3HA using EcoRI and SmaI restriction sites.

The sequences encoding either the cytosolic domain (a.a 33-363) or the transmembrane domain (a.a 1-32) of Msp1 were amplified by PCR using the pGEM4-YK-Msp1-3HA plasmid as a template. The sequence encoding either the cytosolic domain (a.a 35-302) or the transmembrane domain (a.a 1-39) of Mcrl were amplified by PCR using pGEM4-YK-Mcr13HA plasmid as a template. The sequences encoding either the cytosolic domain (a.a 33-183) or the transmembrane domain (a.a 1-30) of Tom20 were amplified by PCR using the pGEM4YK-Tom20-3HA plasmid as a template. The sequences encoding either the cytosolic domain 
with suitable restriction sites into the pGEM4polyA-3HA plasmid for their translation in yeast extract. In all the constructs mentioned above the yeast Kozak (YK) sequence was introduced via a primer directly upstream of the start codon. All primers and plasmids used in this study are listed in Tables S3 and S4, respectively.

\section{Protein purification}

Recombinant cBag and C90 were expressed in BL21 cells from the plasmid pPROEX-HTacBag or pPROEX-HTa-C90, respectively (Young et al., 2003). Expression was induced for 4 h with $1 \mathrm{mM}$ IPTG at $37^{\circ} \mathrm{C}$. The cells were harvested, resuspended in French Press buffer (40 mM HEPES, $100 \mathrm{mM} \mathrm{KCl,} 20 \mathrm{mM}$ imidazole, $2 \mathrm{mM}$ PMSF, EDTA-free cOmplete protease inhibitor [Roche], $\mathrm{pH}$ 7.5) for 1 hour followed by homogenization using tight douncer. Cells were then lysed with an EmulsiFlex-C5 French Press. The cell lysate was subjected to a clarifying spin $\left(15000 \mathrm{x} \mathrm{g}, 15 \mathrm{~min}, 4^{\circ} \mathrm{C}\right)$ and the supernatants were incubated overnight with $2 \mathrm{~mL}$ Ni-NTA Agarose beads (Cube Biotech). The bound proteins were washed with $20 \mathrm{~mL}$ wash buffer (40 mM HEPES, $100 \mathrm{mM} \mathrm{KCl,} 50 \mathrm{mM}$ imidazole, $\mathrm{pH}$ 7.5) and eluted with elution buffer (40 mM HEPES, 100 mM KCl, 300 mM imidazole, $\mathrm{pH}$ 7.5).

GST, GST-Tom70 and GST-Tom20 were expressed and purified as described earlier (Papić et al., 2013).

\section{Biochemical procedures}

Protein samples for immunodecoration were analyzed on 8, 10, 12, or 15\% SDS-PAGE and subsequently transferred onto nitrocellulose membranes by semi-dry Western blotting. Proteins were detected by incubating the membranes first with primary antibodies and then with horseradish peroxidase-conjugates of either goat anti-rabbit or goat anti-rat secondary antibodies. A list of antibodies used in this study is included in Table S5.

Mitochondria were isolated from WT yeast cells for in vitro imports by differential centrifugation as described. Pull-down assays with in vitro translated proteins were performed using cell-free yeast extract as described before (Jores et al., 2018).

\section{In vitro translation and GST Pull-down}

Purified GST and GST-recombinant proteins (GST-Tom20 and GST-Tom70) were incubated with glutathione sepharose beads for 1 hour followed by 1 hour blocking with 5\% BSA in GST basic buffer (20 mM Hepes, $100 \mathrm{mM} \mathrm{NaCl}, 1 \mathrm{mM} \mathrm{MgCl}$, protease inhibitor mix, $\mathrm{pH}$ 7.25). The beads with the bound GST-proteins were centrifuged $\left(500 \mathrm{xg}, 1 \mathrm{~min}, 2{ }^{\circ} \mathrm{C}\right)$. In-vitro 
translated HA-tagged proteins were centrifuged $\left(100000 \mathrm{xg}, 60 \mathrm{~min}, 2^{\circ} \mathrm{C}\right)$ to remove ribosomes and aggregated proteins and were then mixed with the beads for 1 hour. An aliquot of $2 \%$ of the translated material was taken as input. The reaction was supplemented with ATP every 30 minutes. The beads were then washed three times with GST basic buffer and the bound material was eluted by incubating the beads for $10 \mathrm{~min}$ at $95^{\circ} \mathrm{C}$ in $4 \mathrm{x}$ sample buffer supplemented with $0.05 \% \beta$-ME. Eluted material was analysed by SDS-PAGE followed by Ponceau staining and western blotting using antibody against either the indicated proteins or the HA tag.

\section{In vitro translation and import of radiolabeled proteins}

Yeast extracts for in vitro translation were prepared as described ( $\mathrm{Wu}$ and Sachs, 2014). For the preparation of yeast extracts from Ydj1- and Sis1-depleted cells, cells were grown for $8 \mathrm{~h}$ in the presence of $2 \mu \mathrm{g} / \mathrm{mL}$ doxycycline prior to extract preparation.

Proteins were synthesized in yeast extract lysate after in vitro transcription by SP6 polymerase from pGEM4 vectors. Radiolabeled proteins were synthesized for 30 minutes in the presence of 35S-labeled Methionine and Cysteine. After translation, the reactions were supplemented with $58 \mathrm{mM}$ "cold" Methionine-Cysteine mix and 1.5 M Sucrose followed by centrifugation (100000xg, $60 \mathrm{~min}, 2{ }^{\circ} \mathrm{C}$ ) to remove ribosomes and aggregated proteins. The supernatant was diluted with import buffer ( $250 \mathrm{mM}$ sucrose, $0.25 \mathrm{mg} / \mathrm{ml} \mathrm{BSA,} 80 \mathrm{mM} \mathrm{KCl}, 5 \mathrm{mM} \mathrm{MgCl} 2,10$ $\mathrm{mM}$ MOPS, $2 \mathrm{mM}$ NADH, $2 \mathrm{mM}$ ATP, $\mathrm{pH}$ 7.2). Where indicated, the supernatant was supplemented with $20 \mu \mathrm{M}$ cBag or, as a control, with an equivalent amount of BSA. Isolated mitochondria were diluted in import buffer and supplemented with $4 \mathrm{mM}$ ATP and $2 \mathrm{mM}$ $\mathrm{NADH}$ and, where indicated, with $20 \mu \mathrm{M}$ of C90. Some samples were treated with $40 \mu \mathrm{g} / \mathrm{ml}$ of trypsin. The import reactions were started by addition of the radiolabeled proteins to the samples containing the isolated organelles and further incubation at $25^{\circ} \mathrm{C}$ for the indicated times. The import reactions were stopped by diluting the samples with SEM-K80 buffer (250 $\mathrm{mM}$ sucrose, $80 \mathrm{mM} \mathrm{KCl}, 10 \mathrm{mM}$ MOPS, $1 \mathrm{mM}$ EDTA, $\mathrm{pH}$ 7.2) and re-isolation of mitochondria $\left(13200 \mathrm{xg}, 2 \mathrm{~min}, 2{ }^{\circ} \mathrm{C}\right)$. The import of the proteins was analyzed by carbonate extraction. To that aim, the re-isolated mitochondria were resuspended in $0.1 \mathrm{M} \mathrm{Na} 2 \mathrm{CO} 3$, incubated on ice for $30 \mathrm{~min}$, and re-isolated by centrifugation $\left(100000 \mathrm{xg}, 30 \mathrm{~min}, 2{ }^{\circ} \mathrm{C}\right)$. The pellets were resuspended in $2 \mathrm{x}$ sample buffer, incubated for $10 \mathrm{~min}$ at $95^{\circ} \mathrm{C}$ and subjected to SDS-PAGE followed by western blotting and/or autoradiography. Quantifications of bands intensities were obtained using the software AIDA Image Analyzer. Values obtained by AIDA were analysed and formatted into graphs using Excel software. 


\section{Fluorescence anisotropy}

581

582

583

584

585

586

587

588

589

590

591

592

593

594

595

596

597

598

599

600

601

602

603

604

605

606

607

608

609

610

Peptides corresponding to the transmembrane domains of either Mcr1 or Tom70 were synthesized as described previously (Jores et al., 2016). Next, the peptides were coupled to TAMRA and used for the determination of binding interactions and affinities of peptide/(co)chaperone complexes by fluorescence anisotropy. Measurements were performed at $30^{\circ} \mathrm{C}$ in a Jasco FP-8500 Fluorospectrometer equipped with polarizers. Excitation and emission wavelength were set to $554 \mathrm{~nm}$ and $579 \mathrm{~nm}$, respectively. Samples containing $2 \mu \mathrm{M}$ TAMRA-labeled peptide were equilibrated for 15 min before $10 \mu \mathrm{M}$ Ssa1, $30 \mu \mathrm{M}$ Sis $1,10 \mu \mathrm{M}$ GST-Tom70, $10 \mu \mathrm{M}$ BSA or $1 \mathrm{mM} \mathrm{ATP}$ in the indicated order or alone were added. For affinity measurements, $2 \mu \mathrm{M}$ TAMRA-labeled peptides were supplemented with the indicated concentrations of Ssa1 or Sis1 and the difference in anisotropy of bound and free peptide were plotted against the (co)chaperone concentration.

For the sequential anisotropy measurements: Each experiment was performed in triplicates including biological duplicates (two independent protein purifications). For kD measurements the experiments were performed in triplicates, including biological duplicates (two independent protein purifications). The data analysis was performed using the OriginLab software. The mean value of each triplicate was calculated, and the delta anisotropy values plotted against the concentration the stated protein. A Hill fit was performed to calculate the $\mathrm{kD}$ value.

\section{NanoLC-MS/MS analysis and data processing}

Coomassie-stained gel pieces were digested in gel with trypsin, and desalted peptide mixtures (Rappsilber et al., 2007) were separated on an Easy-nLC 1200 coupled to a Q Exactive HF mass spectrometer (both Thermo Fisher Scientific) as described elsewhere (Kliza et al., 2017) with slight modifications: peptide mixtures were separated using a 57 minute segmented gradient of $10-33-50-90 \%$ of HPLC solvent B ( $80 \%$ acetonitrile in $0.1 \%$ formic acid) in HPLC solvent A ( $0.1 \%$ formic acid) at a flow rate of $200 \mathrm{nl} / \mathrm{min}$. In each scan cycle, the seven most intense precursor ions were sequentially fragmented using higher energy collisional dissociation (HCD) fragmentation. In all measurements, sequenced precursor masses were excluded from further selection for $30 \mathrm{sec}$. The target values for MS/MS fragmentation were 105 charges, and for the MS scan 3x106 charges. 
611 Acquired MS spectra were processed with MaxQuant software package version 1.6.7.0 (Cox 612 and Mann, 2008) with integrated Andromeda search engine (Cox et al., 2011). Database search 613 was performed against a target-decoy Saccharomyces cerevisiae database obtained from 614 Uniprot containing 6078 protein entries, and 286 commonly observed contaminants. In 615 database search, full trypsin digestion specificity was required and up to two missed cleavages 616 were allowed. Carbamidomethylation of cysteine was set as fixed modification; protein N617 terminal acetylation, and oxidation of methionine were set as variable modifications. Initial 618 precursor mass tolerance was set to $4.5 \mathrm{ppm}$ and $20 \mathrm{ppm}$ at the MS/MS level. A false discovery 619 rate of $1 \%$ was applied at the peptide and protein level. The mass spectrometry proteomics data 620 have been deposited to the ProteomeXchange Consortium via the PRIDE partner repository 621 with the dataset identifier PXD031610.

\section{Acknowledgments}

624 We thank E. Kracker for excellent technical assistance and T. Becker for antibodies. This work 625 was supported by the Deutsche Forschungsgemeinschaft (RA 1028/10-2 to D.R.). L.D. was supported by a long-term fellowship from the Minerva Foundation.

627

The authors declare no competing financial interests. 


\section{References}

Ahting, U., T. Waizenegger, W. Neupert, and D. Rapaport. 2005. Signal-anchored proteins follow a unique insertion pathway into the outer membrane of mitochondria. The Journal of biological chemistry. 280:48-53. doi:10.1074/JBC.M410905200.

Backes, S., Y.S. Bykov, T. Flohr, M. Räschle, J. Zhou, S. Lenhard, L. Krämer, T. Mühlhaus, C. Bibi, C. Jann, J.D. Smith, L.M. Steinmetz, D. Rapaport, Z. Storchová, M. Schuldiner, F. Boos, and J.M. Herrmann. 2021. The chaperone-binding activity of the mitochondrial surface receptor Tom 70 protects the cytosol against mitoprotein-induced stress. Cell reports. 35. doi:10.1016/J.CELREP.2021.108936.

Becker, T., S. Pfannschmidt, B. Guiard, D. Stojanovski, D. Milenkovic, S. Kutik, N. Pfanner, C. Meisinger, and N. Wiedemann. 2008. Biogenesis of the mitochondrial TOM complex: Mim1 promotes insertion and assembly of signal-anchored receptors. The Journal of biological chemistry. 283:120-127. doi:10.1074/JBC.M706997200.

Bhangoo, M.K., S. Tzankov, A.C.Y. Fan, K. Dejgaard, D.Y. Thomas, and J.C. Young. 2007. Multiple 40-kDa heat-shock protein chaperones function in Tom70-dependent mitochondrial import. Molecular biology of the cell. 18:3414-3428. doi:10.1091/MBC.E07-01-0088.

Bohush, A., P. Bieganowski, and A. Filipek. 2019. Hsp90 and Its Co-Chaperones in Neurodegenerative Diseases. International journal of molecular sciences. 20. doi:10.3390/IJMS20204976.

Caplan, A.J., D.M. Cyr, and M.G. Douglas. 1992. YDJ1p facilitates polypeptide translocation across different intracellular membranes by a conserved mechanism. Cell. 71:1143-1155. doi:10.1016/S0092-8674(05)80063-7.

Cashikar, A.G., M. Duennwald, and S.L. Lindquist. 2005. A chaperone pathway in protein disaggregation. Hsp26 alters the nature of protein aggregates to facilitate reactivation by Hsp104. The Journal of biological chemistry. 280:23869-23875. doi:10.1074/JBC.M502854200.

Chaari, A. 2019. Molecular chaperones biochemistry and role in neurodegenerative diseases. International journal of biological macromolecules. 131:396-411. doi:10.1016/J.IJBIOMAC.2019.02.148.

Chen, Y., G.K.E. Umanah, N. Dephoure, S.A. Andrabi, S.P. Gygi, T.M. Dawson, V.L. Dawson, and J. Rutter. 2014. Msp1/ATAD1 maintains mitochondrial function by facilitating the degradation of mislocalized tail-anchored proteins. The EMBO journal. 33:1548-1564. doi:10.15252/EMBJ.201487943.

Cichocki, B.A., K. Krumpe, D.G. Vitali, and D. Rapaport. 2018. Pex19 is involved in importing dually targeted tail-anchored proteins to both mitochondria and peroxisomes. Traffic. 19:770-785. doi:10.1111/TRA.12604. 
Clerico, E.M., J.M. Tilitsky, W. Meng, and L.M. Gierasch. 2015. How hsp70 molecular machines interact with their substrates to mediate diverse physiological functions. Journal of molecular biology. 427:1575-1588. doi:10.1016/J.JMB.2015.02.004.

Collier, M.P., and J.L.P. Benesch. 2020. Small heat-shock proteins and their role in mechanical stress. Cell stress \& chaperones. 25:601-613. doi:10.1007/S12192-020-01095-Z.

Cox, J., and M. Mann. 2008. MaxQuant enables high peptide identification rates, individualized p.p.b.-range mass accuracies and proteome-wide protein quantification. Nature biotechnology. 26:1367-1372. doi:10.1038/NBT.1511.

Cox, J., N. Neuhauser, A. Michalski, R.A. Scheltema, J. v. Olsen, and M. Mann. 2011. Andromeda: a peptide search engine integrated into the MaxQuant environment. Journal of proteome research. 10:1794-1805. doi:10.1021/PR101065J.

Cry, D.M. 1995. Cooperation of the molecular chaperone Ydj1 with specific Hsp70 homologs to suppress protein aggregation. FEBS letters. 359:129-132. doi:10.1016/00145793(95)00024-4.

Deshaies, R.J., B.D. Koch, M. Werner-Washburne, E.A. Craig, and R. Schekman. 1988. A subfamily of stress proteins facilitates translocation of secretory and mitochondrial precursor polypeptides. Nature. 332:800-805. doi:10.1038/332800A0.

Doan, K.N., A. Grevel, C.U. Mårtensson, L. Ellenrieder, N. Thornton, L.S. Wenz, Ł. Opaliński, B. Guiard, N. Pfanner, and T. Becker. 2020. The Mitochondrial Import Complex MIM Functions as Main Translocase for $\alpha$-Helical Outer Membrane Proteins. Cell reports. 31. doi:10.1016/J.CELREP.2020.107567.

Drwesh, L., and D. Rapaport. 2020. Biogenesis pathways of $\alpha$-helical mitochondrial outer membrane proteins. Biological Chemistry. 401:677-686. doi:10.1515/HSZ-2019-0440.

Endo, T., S. Mitsui, M. Nakai, and D. Roise. 1996. Binding of mitochondrial presequences to yeast cytosolic heat shock protein 70 depends on the amphiphilicity of the presequence. The Journal of biological chemistry. 271:4161-4167. doi:10.1074/JBC.271.8.4161.

Fan, A.C.Y., L.M. Gava, C.H.I. Ramos, and J.C. Young. 2010. Human mitochondrial import receptor Tom70 functions as a monomer. The Biochemical journal. 429:553-563. doi:10.1042/BJ20091855.

Fan, A.C.Y., G. Kozlov, A. Hoegl, R.C. Marcellus, M.J.H. Wong, K. Gehring, and J.C. Young. 2011. Interaction between the human mitochondrial import receptors Tom 20 and Tom70 in vitro suggests a chaperone displacement mechanism. The Journal of biological chemistry. 286:32208-32219. doi:10.1074/JBC.M111.280446.

Franzmann, T.M., M. Wühr, K. Richter, S. Walter, and J. Buchner. 2005. The Activation Mechanism of Hsp26 does not Require Dissociation of the Oligomer. Journal of Molecular Biology. 350:1083-1093. doi:10.1016/J.JMB.2005.05.034.

Gnanasundram, S.V., and M. Koš. 2015. Fast protein-depletion system utilizing tetracycline repressible promoter and $\mathrm{N}$-end rule in yeast. Molecular biology of the cell. 26:762-768. doi:10.1091/MBC.E14-07-1186. 
Hahne, K., V. Haucke, L. Ramage, and G. Schatz. 1994. Incomplete arrest in the outer membrane sorts NADH-cytochrome b5 reductase to two different submitochondrial compartments. Cell. 79:829-839. doi:10.1016/0092-8674(94)90072-8.

Haslbeck, M., A. Miess, T. Stromer, S. Walter, and J. Buchner. 2005. Disassembling protein aggregates in the yeast cytosol. The cooperation of Hsp26 with Ssa1 and Hsp104. The Journal of biological chemistry. 280:23861-23868. doi:10.1074/JBC.M502697200.

Haslbeck, M., S. Weinkauf, and J. Buchner. 2019. Small heat shock proteins: Simplicity meets complexity. The Journal of Biological Chemistry. 294:2121. doi:10.1074/JBC.REV118.002809.

Hettema, E.H., C.C.M. Ruigrok, M.G. Koerkamp, M. van den Berg, H.F. Tabak, B. Distel, and I. Braakman. 1998a. The cytosolic DnaJ-like protein djplp is involved specifically in peroxisomal protein import. The Journal of cell biology. 142:421-434. doi:10.1083/JCB.142.2.421.

Hettema, E.H., C.C.M. Ruigrok, M.G. Koerkamp, M. van den Berg, H.F. Tabak, B. Distel, and I. Braakman. 1998b. The cytosolic DnaJ-like protein djplp is involved specifically in peroxisomal protein import. The Journal of cell biology. 142:421-434. doi:10.1083/JCB.142.2.421.

Hoseini, H., S. Pandey, T. Jores, A. Schmitt, M. Franz-Wachtel, B. Macek, J. Buchner, K.S. Dimmer, and D. Rapaport. 2016. The cytosolic cochaperone Stil is relevant for mitochondrial biogenesis and morphology. The FEBS journal. 283:3338-3352. doi:10.1111/FEBS.13813.

Jansen, R.L.M., and I.J. van der Klei. 2019. The peroxisome biogenesis factors Pex3 and Pex19: multitasking proteins with disputed functions. FEBS letters. 593:457-474. doi:10.1002/1873-3468.13340.

Johnson, J.L., and E.A. Craig. 2001. An essential role for the substrate-binding region of Hsp40s in Saccharomyces cerevisiae. The Journal of cell biology. 152:851-856. doi:10.1083/JCB.152.4.851.

Jores, T., A. Klinger, L.E. Groß, S. Kawano, N. Flinner, E. Duchardt-Ferner, J. Wöhnert, H. Kalbacher, T. Endo, E. Schleiff, and D. Rapaport. 2016. Characterization of the targeting signal in mitochondrial $\beta$-barrel proteins. Nature communications. 7. doi:10.1038/NCOMMS12036.

Jores, T., J. Lawatscheck, V. Beke, M. Franz-Wachtel, K. Yunoki, J.C. Fitzgerald, B. Macek, T. Endo, H. Kalbacher, J. Buchner, and D. Rapaport. 2018. Cytosolic Hsp70 and Hsp40 chaperones enable the biogenesis of mitochondrial $\beta$-barrel proteins. Journal of Cell Biology. 217:3091-3108. doi:10.1083/JCB.201712029.

Kampinga, H.H., and E.A. Craig. 2010. The HSP70 chaperone machinery: J proteins as drivers of functional specificity. Nature reviews. Molecular cell biology. 11:579-592. doi:10.1038/NRM2941. 
Klaips, C.L., M.H.M. Gropp, M.S. Hipp, and F.U. Hartl. 2020. Sis1 potentiates the stress response to protein aggregation and elevated temperature. Nature Communications 2020 11:1. 11:1-16. doi:10.1038/s41467-020-20000-x.

Kliza, K., C. Taumer, I. Pinzuti, M. Franz-Wachtel, S. Kunzelmann, B. Stieglitz, B. MacEk, and K. Husnjak. 2017. Internally tagged ubiquitin: a tool to identify linear polyubiquitinmodified proteins by mass spectrometry. Nature methods. 14:504-512. doi:10.1038/NMETH.4228.

Komiya, T., S. Rospert, G. Schatz, and K. Mihara. 1997. Binding of mitochondrial precursor proteins to the cytoplasmic domains of the import receptors Tom70 and Tom20 is determined by cytoplasmic chaperones. The EMBO journal. 16:4267-4275. doi:10.1093/EMBOJ/16.14.4267.

Kreimendahl, S., and J. Rassow. 2020. The Mitochondrial Outer Membrane Protein Tom70Mediator in Protein Traffic, Membrane Contact Sites and Innate Immunity. International journal of molecular sciences. 21:1-32. doi:10.3390/IJMS21197262.

Lamb, D.C., D.E. Kelly, N.J. Manning, M.A. Kaderbhai, and S.L. Kelly. 1999. Biodiversity of the P450 catalytic cycle: yeast cytochrome b5/NADH cytochrome b5 reductase complex efficiently drives the entire sterol 14-demethylation (CYP51) reaction. FEBS letters. 462:283-288. doi:10.1016/S0014-5793(99)01548-3.

Li, J., X. Qian, and B. Sha. 2009. Heat shock protein 40: structural studies and their functional implications. Protein and peptide letters. 16:606-612. doi:10.2174/092986609788490159.

Meineke, B., G. Engl, C. Kemper, A. Vasiljev-Neumeyer, H. Paulitschke, and D. Rapaport. 2008. The outer membrane form of the mitochondrial protein Mcr1 follows a TOMindependent membrane insertion pathway. FEBS letters. 582:855-860. doi:10.1016/J.FEBSLET.2008.02.009.

Mills, R.D., J. Trewhella, T.W. Qiu, T. Welte, T.M. Ryan, T. Hanley, R.B. Knott, T. Lithgow, and T.D. Mulhern. 2009. Domain organization of the monomeric form of the Tom70 mitochondrial import receptor. Journal of molecular biology. 388:1043-1058. doi:10.1016/J.JMB.2009.03.070.

Mokry, D.Z., J. Abrahão, and C.H.I. Ramos. 2015. Disaggregases, molecular chaperones that resolubilize protein aggregates. Anais da Academia Brasileira de Ciências. 87:1273-1292. doi:10.1590/0001-3765201520140671.

Neupert, W., and J.M. Herrmann. 2007. Translocation of proteins into mitochondria. Annual review of biochemistry. 76:723-749. doi: 10.1146/ANNUREV.BIOCHEM. 76.052705.163409.

Neupert, W., and N. Pfanner. 1993. Roles of molecular chaperones in protein targeting to mitochondria. Philosophical transactions of the Royal Society of London. Series B, Biological sciences. 339. doi:10.1098/RSTB.1993.0034. 
Okreglak, V., and P. Walter. 2014. The conserved AAA-ATPase Msp1 confers organelle specificity to tail-anchored proteins. Proceedings of the National Academy of Sciences of the United States of America. 111:8019-8024. doi:10.1073/PNAS.1405755111.

Opaliński, Ł., J. Song, C. Priesnitz, L.S. Wenz, S. Oeljeklaus, B. Warscheid, N. Pfanner, and T. Becker. 2018. Recruitment of Cytosolic J-Proteins by TOM Receptors Promotes Mitochondrial Protein Biogenesis. Cell reports. 25:2036-2043.e5. doi:10.1016/J.CELREP.2018.10.083.

Papić, D., Y. Elbaz-Alon, S.N. Koerdt, K. Leopold, D. Worm, M. Jung, M. Schuldiner, and D. Rapaport. 2013. The role of Djp1 in import of the mitochondrial protein Mim1 demonstrates specificity between a cochaperone and its substrate protein. Molecular and cellular biology. 33:4083-4094. doi:10.1128/MCB.00227-13.

Popov-Čeleketić, J., T. Waizenegger, and D. Rapaport. 2008. Mim1 functions in an oligomeric form to facilitate the integration of Tom 20 into the mitochondrial outer membrane. Journal of molecular biology. 376:671-680. doi:10.1016/J.JMB.2007.12.006.

Rappsilber, J., M. Mann, and Y. Ishihama. 2007. Protocol for micro-purification, enrichment, pre-fractionation and storage of peptides for proteomics using StageTips. Nature protocols. 2:1896-1906. doi:10.1038/NPROT.2007.261.

Saio, T., X. Guan, P. Rossi, A. Economou, and C.G. Kalodimos. 2014. Structural basis for protein antiaggregation activity of the trigger factor chaperone. Science (New York, N.Y.). 344. doi:10.1126/SCIENCE.1250494.

Vitali, D.G., L. Drwesh, B.A. Cichocki, A. Kolb, and D. Rapaport. 2020. The Biogenesis of Mitochondrial Outer Membrane Proteins Show Variable Dependence on Import Factors. iScience. 23. doi:10.1016/J.ISCI.2019.100779.

Wegele, H., S.K. Wandinger, A.B. Schmid, J. Reinstein, and J. Buchner. 2006. Substrate Transfer from the Chaperone Hsp70 to Hsp90. Journal of Molecular Biology. 356:802-811. doi:10.1016/J.JMB.2005.12.008.

Wiedemann, N., and N. Pfanner. 2017. Mitochondrial Machineries for Protein Import and Assembly. Annual review of biochemistry. 86:685-714. doi:10.1146/ANNUREVBIOCHEM-060815-014352.

Wu, C., and M.S. Sachs. 2014. Preparation of a Saccharomyces cerevisiae cell-free extract for in vitro translation. Methods in enzymology. 539:17-28. doi:10.1016/B978-0-12-420120$0.00002-5$.

Wyszkowski, H., A. Janta, W. Sztangierska, I. Obuchowski, T. Chamera, A. Kłosowska, and K. Liberek. 2021. Class-specific interactions between Sis1 J-domain protein and Hsp70 chaperone potentiate disaggregation of misfolded proteins. Proceedings of the National Academy of Sciences. 118:e2108163118. doi:10.1073/PNAS.2108163118.

Xie, J.L., I. Bohovych, E.O.Y. Wong, J.P. Lambert, A.C. Gingras, O. Khalimonchuk, L.E. Cowen, and M.D. Leach. 2017. Ydj1 governs fungal morphogenesis and stress response, 
and facilitates mitochondrial protein import via Mas1 and Mas2. Microbial cell (Graz, Austria). 4:342-361. doi:10.15698/MIC2017.10.594.

821 Yan, W., and E.A. Craig. 1999. The glycine-phenylalanine-rich region determines the specificity of the yeast Hsp40 Sis1. Molecular and cellular biology. 19:7751-7758. doi:10.1128/MCB.19.11.7751.

Young, J.C., N.J. Hoogenraad, and F.U. Hartl. 2003. Molecular chaperones Hsp90 and Hsp70 deliver preproteins to the mitochondrial import receptor Tom70. Cell. 112:41-50. doi:10.1016/S0092-8674(02)01250-3.

Zhou, C., B.D. Slaughter, J.R. Unruh, A. Eldakak, B. Rubinstein, and R. Li. 2011. Motility and segregation of Hsp104-associated protein aggregates in budding yeast. Cell. 147:11861196. doi:10.1016/J.CELL.2011.11.002.

Zolkiewski, M., T. Zhang, and M. Nagy. 2012. Aggregate reactivation mediated by the Hsp100 


\section{Figure legends}

Figure 1: Cytosolic chaperones interact with newly synthesized signal-anchored proteins. (A and B) In-vitro translation reactions using yeast extracts without mRNA (Ø) or programmed with mRNA encoding HA-tagged variants of signal-anchored proteins (Msp1, Mcr1, Tom20 and Tom70), the tail-anchored protein Fis1, the $\beta$-barrel protein Porin, or, as a control, dihydrofolate reductase (DHFR). The reactions were subjected to a pull-down with anti-HA beads. Samples from the input and the eluates were analyzed by SDS-PAGE and immunodecoration with the indicated antibodies. Each experiment was done as three independent repeats. Two different yeast extracts were employed. Each repeat was done with new preparation of mRNA.

Figure 2: Cytosolic chaperones interact with newly synthesized signal-anchored proteins through their transmembrane domain. (A-C) In-vitro translation reactions using yeast extracts without mRNA $(\varnothing)$ or programmed with mRNA encoding HA-tagged versions of DHFR or the full length (FL), cytosolic domain (C) or transmembrane domain (T) of the SA proteins. Mcr1 (A), Msp1 (B) and Tom70 (C). The reactions were subjected to a pull-down with antiHA beads. Samples from the input and the eluates were analyzed by SDS-PAGE and immunodecoration with the indicated antibodies. Each experiment was done as three independent repeats. The same yeast extract was used with different mRNAs in each repeat.

Figure 3: Depletion of both co-chaperones Ydj1 and Sis1 results in decreased steady-state levels of Tom 20 and Tom70 proteins. (A and C) Mitochondrial and cytosolic fractions were

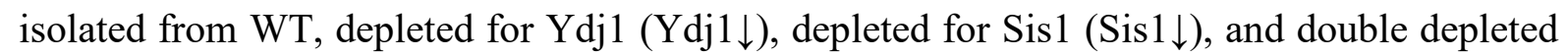
for both co-chaperones (Ydj1 $\downarrow$ Sis $1 \downarrow$ ) yeast cells, after being grown without doxycycline (time $=0$ ) or in the presence of Dox. for 1, 2 or 4 hours. Samples were analyzed by SDS-PAGE followed by immunodecoration with the indicated antibodies. (B and D). Intensities of the bands corresponding to the depicted proteins in the mitochondrial fractions from three independent experiments were quantified and normalized to Ponceau levels. The levels of the proteins in each depletion strain in the absence of doxycycline (time $=0$ ) was set to $100 \%$. Error bars represent \pm SD.

Figure 4: Signal-anchored proteins show variable dependence on Ydj1 and Sis1. (A and B) In vitro import of radiolabeled Tom20 (C) or Tom70 (D) that were translated in either WT or in Ydj1 and Sis1 depleted yeast extract (YS $\downarrow$ ). The radiolabeled proteins were incubated with WT mitochondria for the indicated time points (1, 5, 10 and 20 minutes). After import, 
mitochondria were subjected to alkaline extraction and the pellet was analyzed by SDS-PAGE and autoradiography. Intensities of the bands corresponding to Tom20 and Tom70 were quantified. The intensities of the bands corresponding to import from WT yeast extract after $20 \mathrm{~min}$ were set to $100 \%$. The graph represents the mean values $\pm \mathrm{SD}$ of three independent experiments.

Figure 5: Depletion of Ydj1 and Sis1 can increase the risk for aggregation of newly synthesized proteins. (A and B) In-vitro translation reactions using yeast extracts from either WT cells or from cells depleted for both Ydj1 and Sis1 (YS $\downarrow$ ) were programmed with mRNA encoding HA-tagged versions of the indicated proteins. The reactions were subjected to a pull-down with anti-HA beads. Samples from the input and the eluates were analyzed by SDS-PAGE and immunodecoration with the indicated antibodies.

Figure 6: The hydrophobic segment of signal-anchored proteins interacts with the Hsp70 chaperone and its co-chaperone Sis1. (A and B) The fluorescence anisotropy of TAMRAlabeled peptides corresponding to the TMDs of either Tom70 (A) or Mcr1 (B) was measured in the presence of $10 \mu \mathrm{M}$ Ssal (black circles) or $30 \mu \mathrm{M}$ BSA, as a control (red circles). (C-F) For affinity determinations, the TMD-labelled peptides of either Tom70 (C and E) or Mcr1 (D and F) were mixed with the indicated concentrations of either Ssa1 (C and D) or Sis1 (E and F), and the difference in anisotropy ( $\Delta$ anisotropy) of the bound and free peptide was plotted against the co-chaperone concentration.

Figure 7: The Hsp70 chaperone Ssal is required for proper insertion of signal-anchored proteins. (A and B) Left panels: Radiolabeled Msp1 (A) and Mcr1 (B) were translated in WT yeast extract and subjected to in-vitro import assay using isolated mitochondria. Prior to the import, the yeast extract translation reaction was incubated with either CBag (Hsp70 inhibitor) or with BSA, as a control. After import for the indicated time points, the samples were subjected to carbonate extraction and the pellets fraction were analyzed by SDS-PAGE followed by autoradiography. Right panels: The bands corresponding to Msp1 and Mcr1 were quantified and the results of three independent experiments are presented as mean values $\pm \mathrm{SD}$. The intensities of the bands corresponding to import for $10 \mathrm{~min}$ in the presence of BSA were set to $100 \%$. (C-E) The fluorescence anisotropy of TAMRA-labelled Mcr1-TMD peptide was

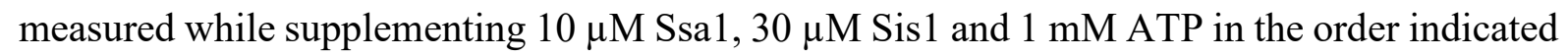
in the various panels. 
Figure 8: Newly synthesized signal-anchored proteins can be recognized by the cytosolic domains of the TOM receptors. (A) HA-tagged versions of the signal-anchored proteins, Mcr1 and Msp1 or of the control protein DHFR, were freshly translated in yeast extract. Next, they were mixed with GST alone or GST fused to the cytosolic domain of either Tom20 (GSTTom20) or Tom70 (GST-Tom70) bound to glutathione beads. Input (2\%) and eluate (100\%) samples were subjected to SDS-PAGE. GST fusion proteins were detected by Ponceau staining whereas SA proteins via immunodecoration with antibodies against the HA-tag. Lower panels: Bands corresponding to Msp1-3HA and Mcr1-3HA from three independent experiments were quantified and the level of binding to GST alone was set as 1. Error bars represent \pm SD. (BE) Fluorescence anisotropy of TAMRA-labeled Mcr1 peptide was monitored after supplementing $10 \mu \mathrm{M}$ Ssa1, $1 \mathrm{mM}$ ATP, or $10 \mu \mathrm{M}$ GST-Tom70 in the indicated order. (E) The first addition was of $10 \mu \mathrm{M}$ Ssa 1 together with $30 \mu \mathrm{M}$ Sis1, followed by addition of $1 \mathrm{mM}$ ATP and then finally $10 \mu \mathrm{M}$ GST-Tom70.

Figure 9: Tom70 and Tom 20 may have offsetting function in mediating the biogenesis of Msp1 and Mcr1. (A and B) Left panels: Radiolabeled Msp1 (A) and Mcr1 (B) were translated in WT yeast extract and subjected to in-vitro import assay using isolated mitochondria. Prior to the import, mitochondria were incubated for 30 minutes in the presence or absence of trypsin. After import for the indicated time points, the samples were subjected to carbonate extraction and the pellet fractions were subjected to SDS-PAGE followed by autoradiography. To verify the activity of the protease, the same membranes were immunodecorated with antibodies against the indicated proteins. Right panels: The bands corresponding to Msp1 and Mcr1 were quantified and the results of three independent experiments are presented as mean values $\pm \mathrm{SD}$. The intensities of the bands corresponding to import for $15 \mathrm{~min}$ in the absence of Trypsin were set to $100 \%$. (C and D) Left panels: Radiolabeled Msp1 (C) and Mcr1 (D) were translated in WT yeast extract and subjected to in-vitro import assay using mitochondria isolated from either WT or tom $20 \Delta$ strain. Prior to the import reactions, mitochondria were incubated in the presence or absence of $20 \mu \mathrm{M} \mathrm{C90} \mathrm{(blocker} \mathrm{of} \mathrm{Tom70).} \mathrm{After} \mathrm{import} \mathrm{for} \mathrm{the} \mathrm{indicated} \mathrm{time}$ points, the samples were subjected to carbonate extraction and the pellet fractions were subjected to SDS-PAGE followed by autoradiography. Right panels: The bands corresponding to Msp1 and Mcr1 were quantified and the results of three independent experiments are presented as mean values \pm SD. The intensities of the bands corresponding to import for 15 min in the absence of $\mathrm{C} 90$ were set to $100 \%$. 
bioRxiv preprint doi: https://doi org/10.1101/2022 02 15.480587 this version posted February 17, 2022. The copyright holder for this preprint (which was not certified by peer review) is the author/funder, who has granted bioRxiv a license to display the preprint in perpetuity. It is made available under aCC-BY 4.0 International license.

A

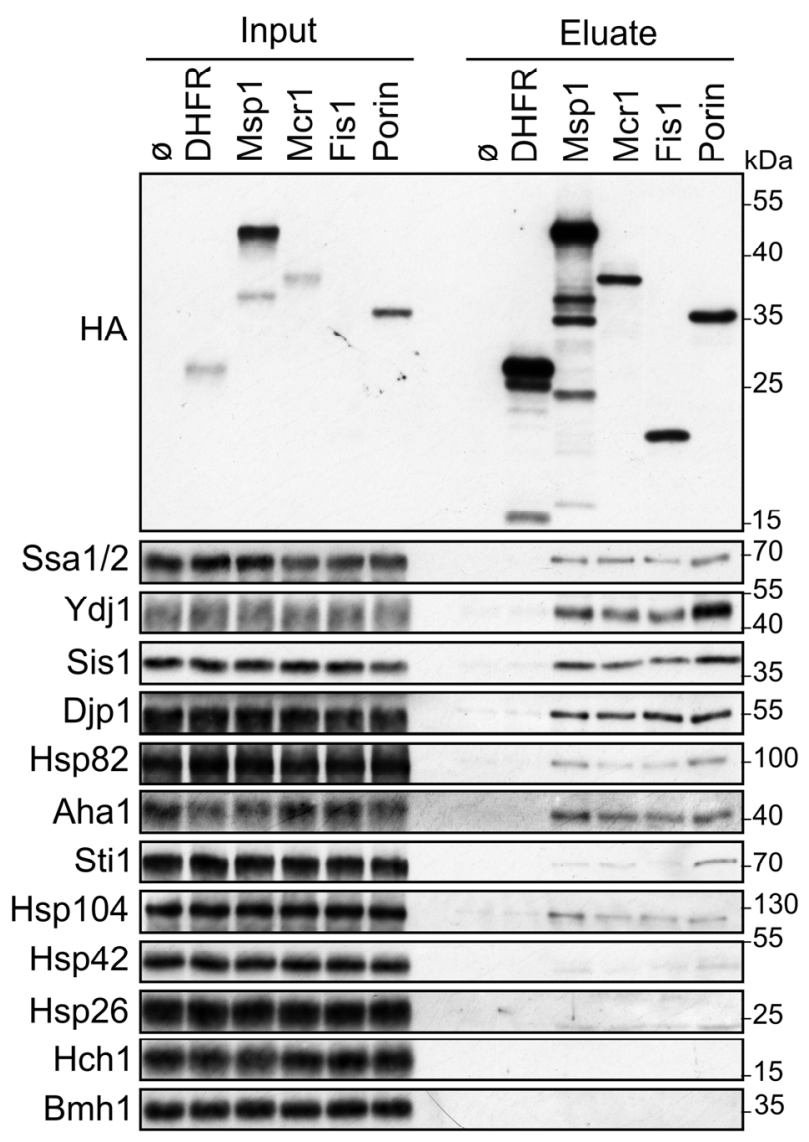

$\mathrm{B}$

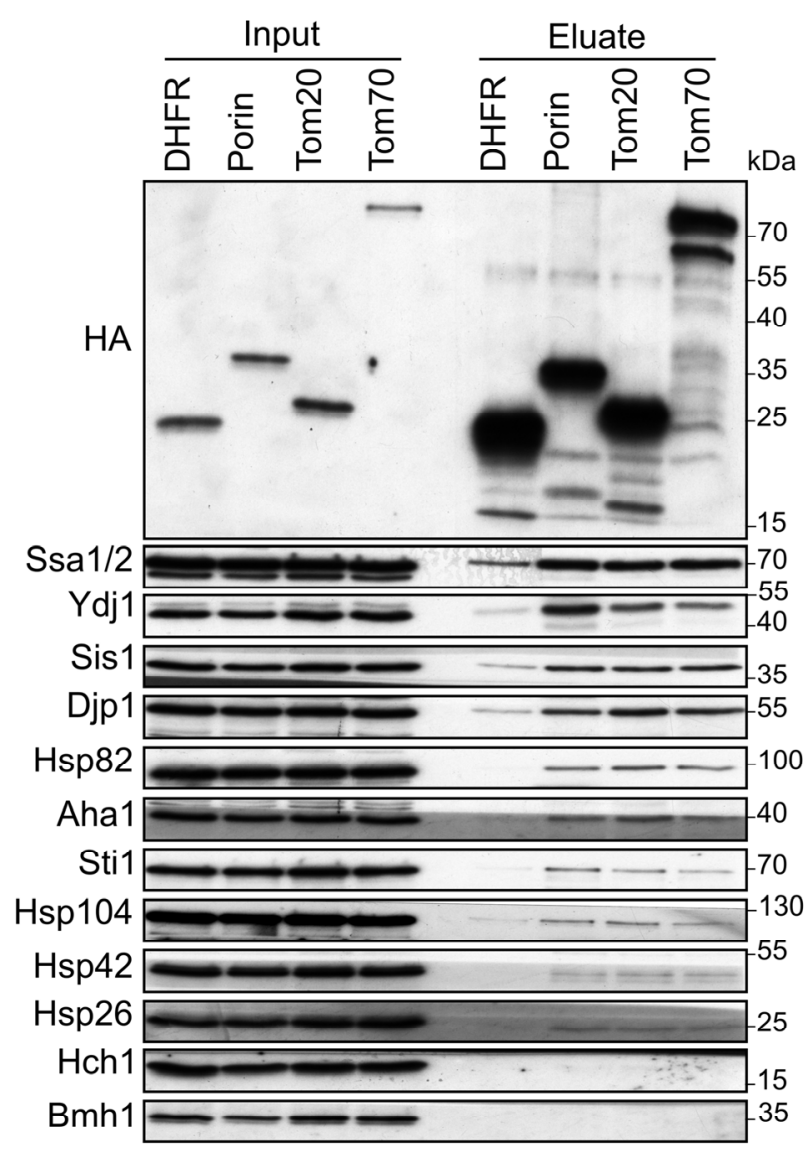




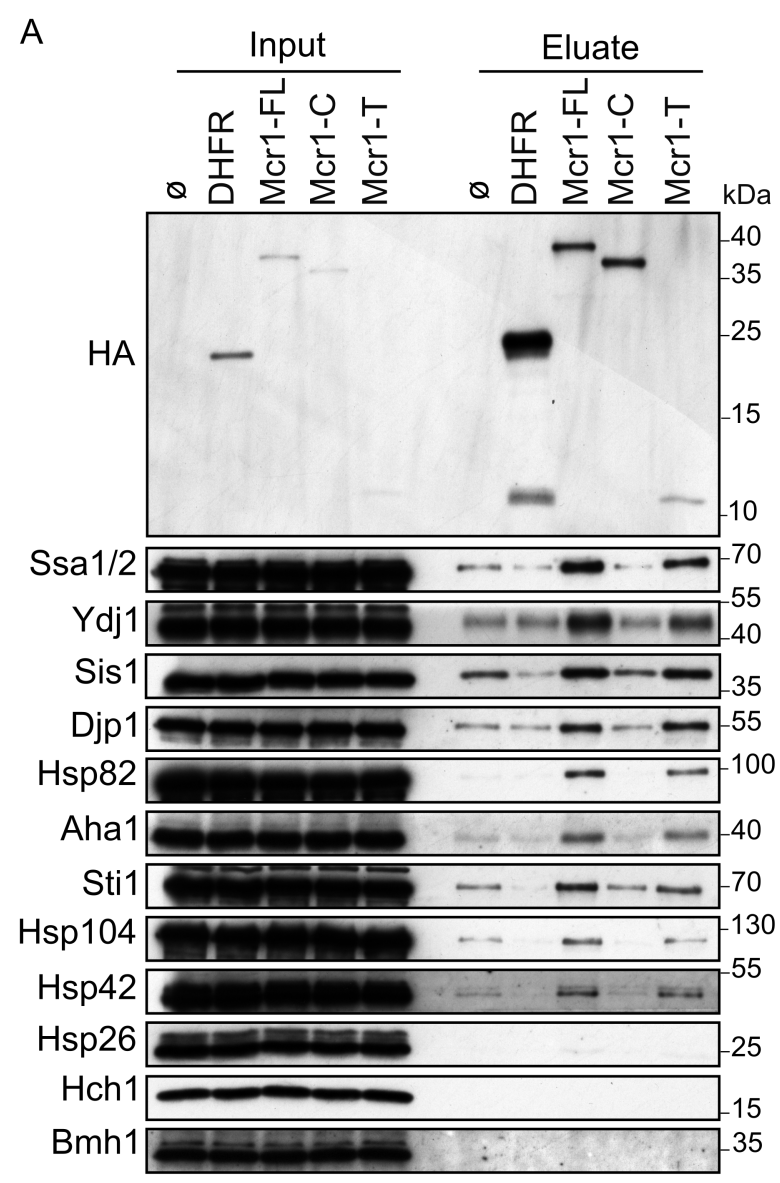

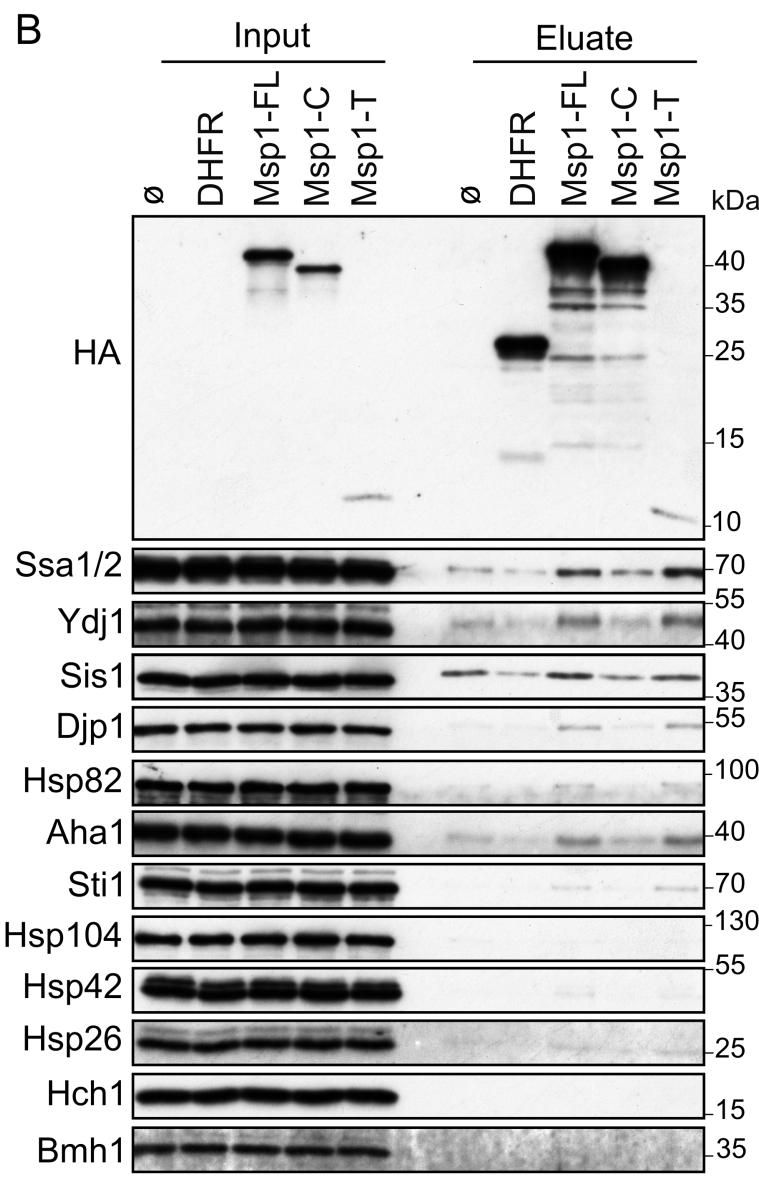

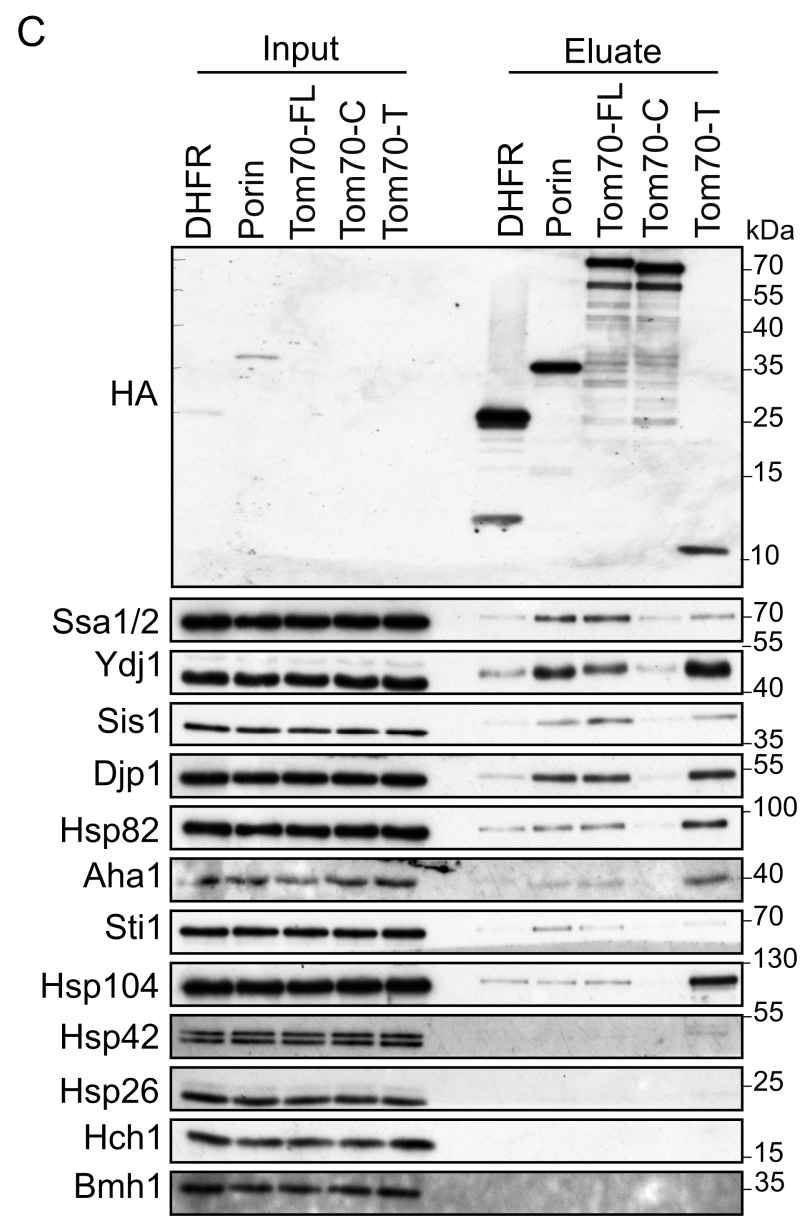


bioRxiv preprint doi: https://doi org/10 1101/2022 02 15.480587 this version posted February 17, 2022. The copyright holder for this preprint (which was not certified by peer review) is the author/funder, who has granted bioRxiv a license to display the preprint in perpetuity. It is made available under aCC-BY 4.0 International license.

A
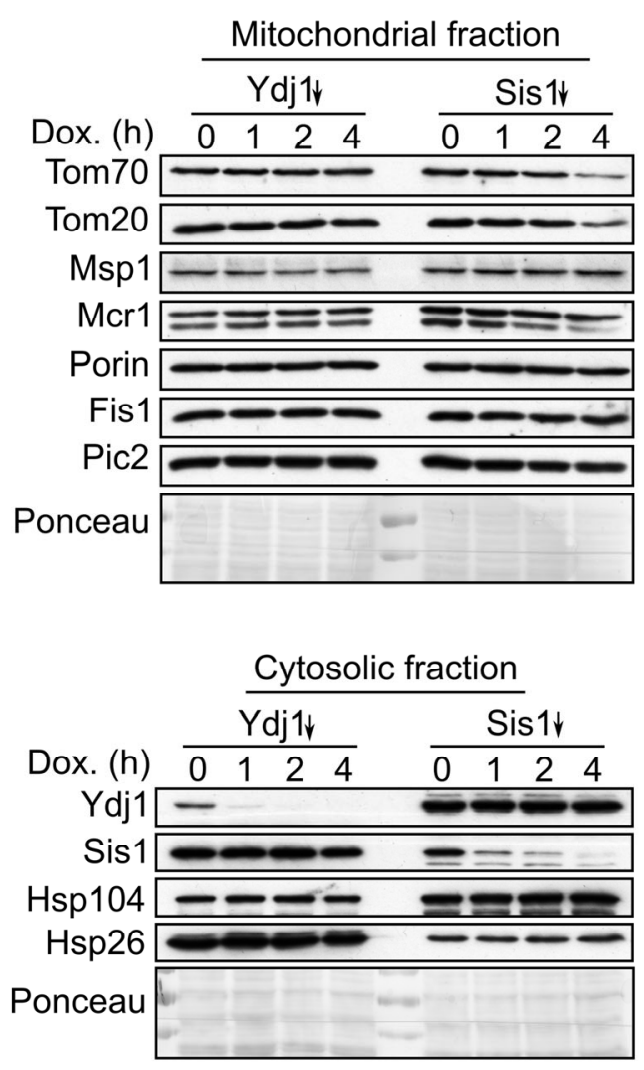

C

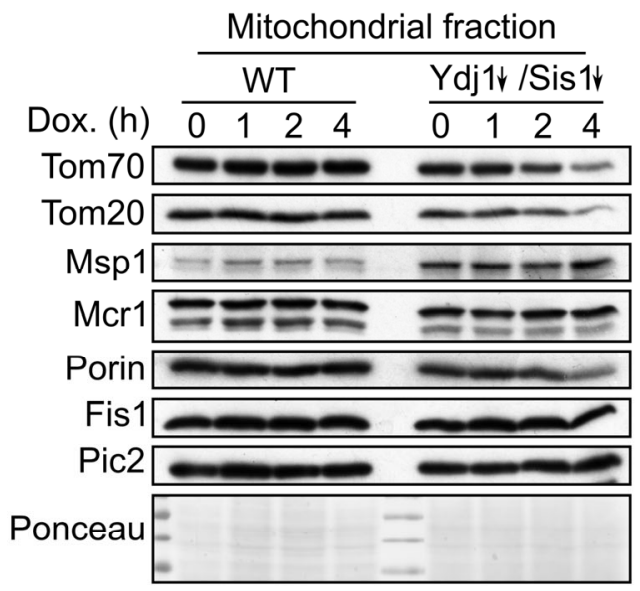

Cytosolic fraction

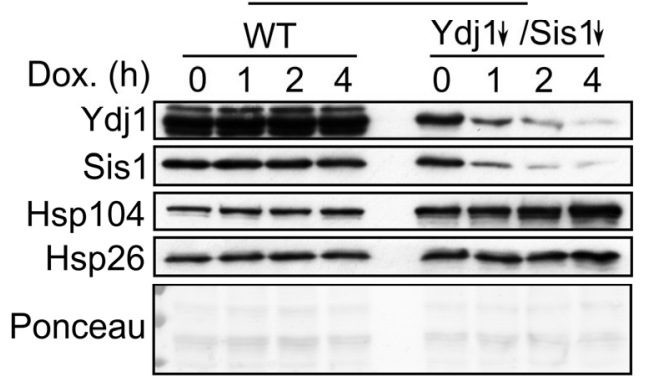

B
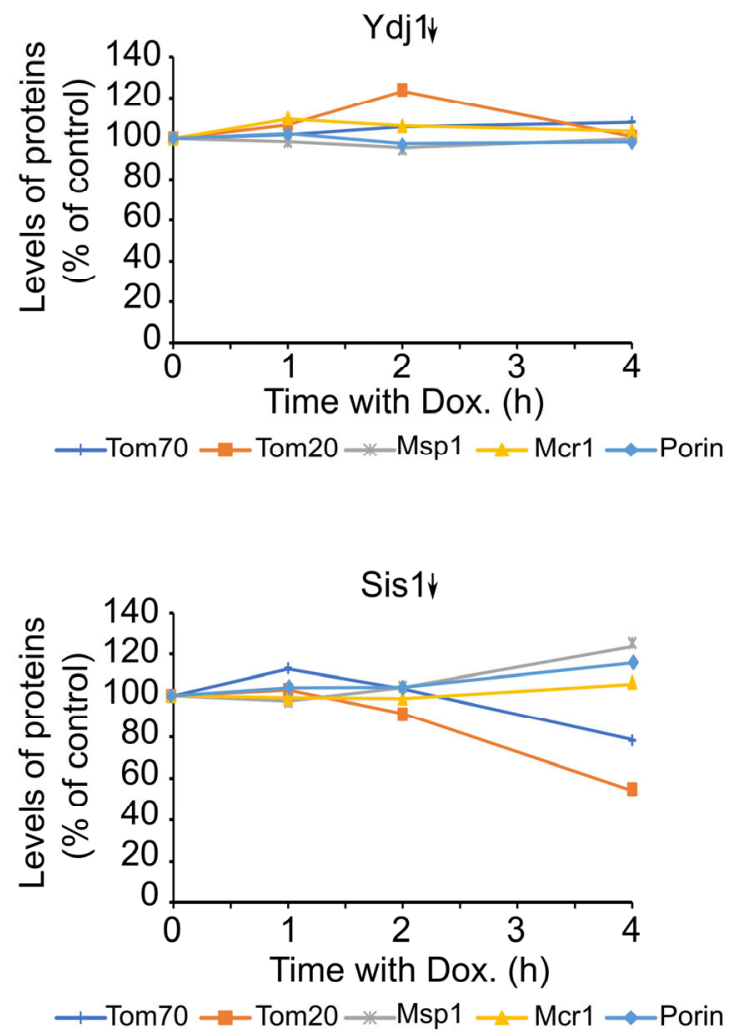

D

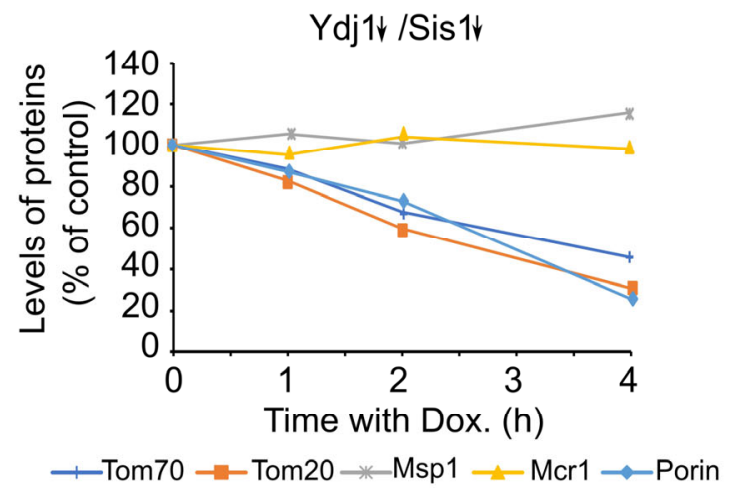


bioRxiv preprint doi: https://doi org/10.1101/2022 02 15.480587 t this version posted February 17, 2022. The copyright holder for this preprint (which was not certified by peer review) is the author/funder, who has granted bioRxiv a license to display the preprint in perpetuity. It is made available under aCC-BY 4.0 International license.

A
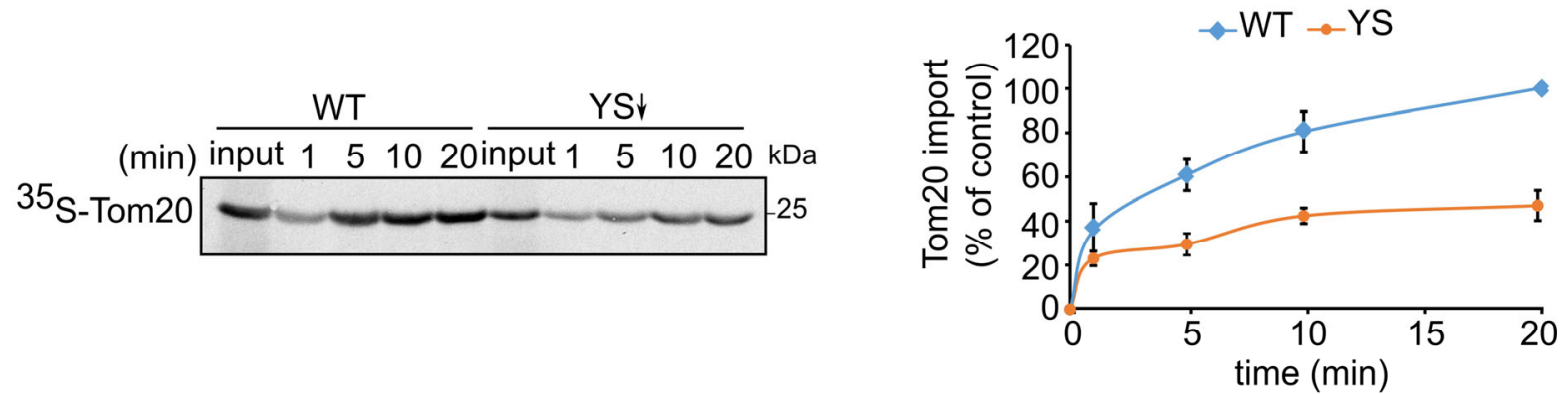

B
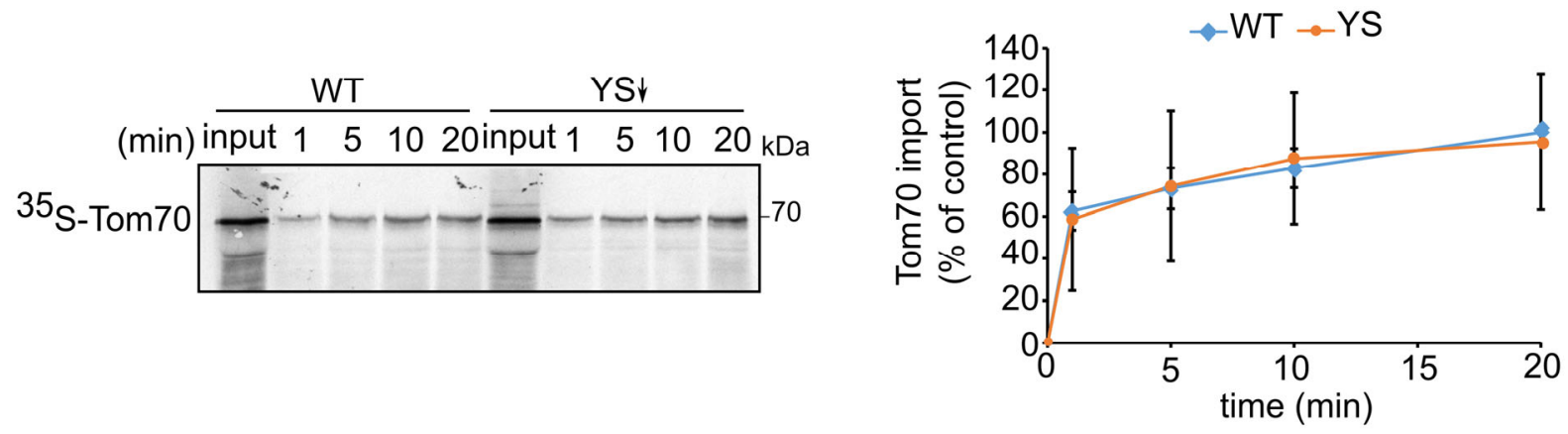
bioRxiv preprint doi: https://doi org/10.1101/2022 02 15.480587 this version posted February 17, 2022. The copyright holder for this preprint (which was not certified by peer review) is the author/funder, who has granted bioRxiv a license to display the preprint in perpetuity. It is made available under aCC-BY 4.0 International license.

A

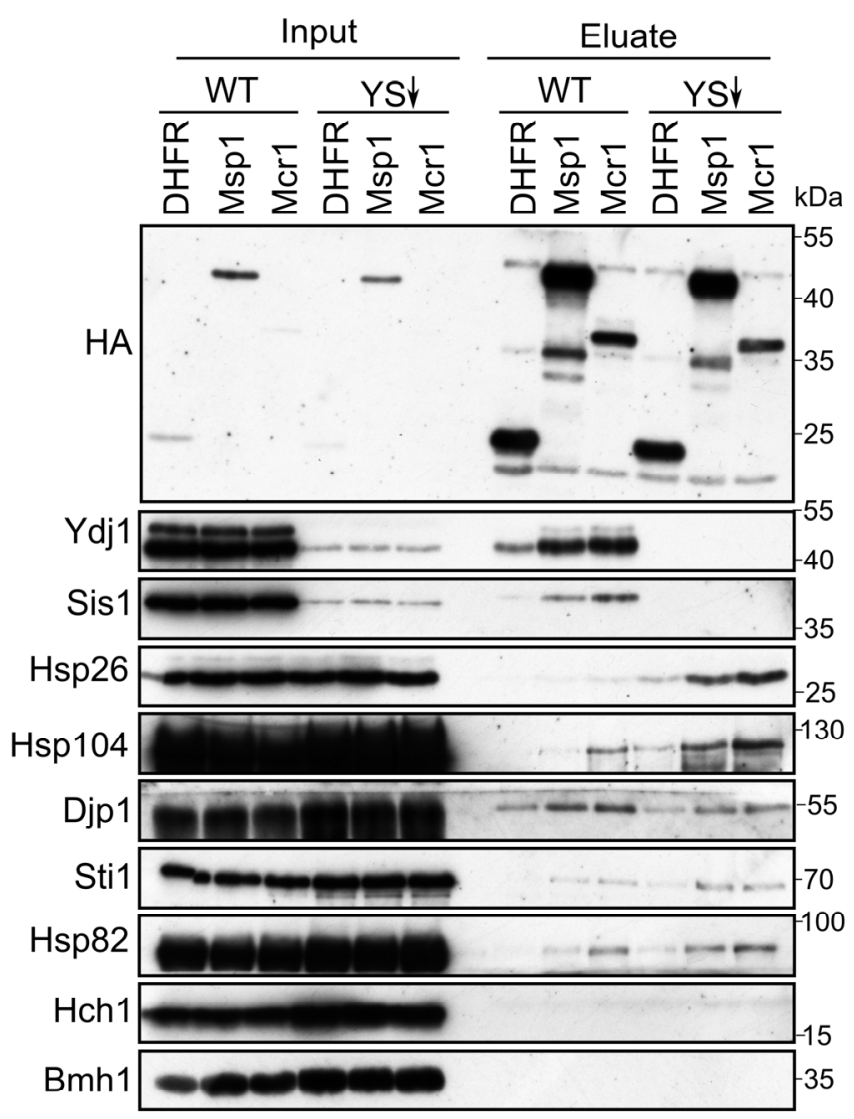

B

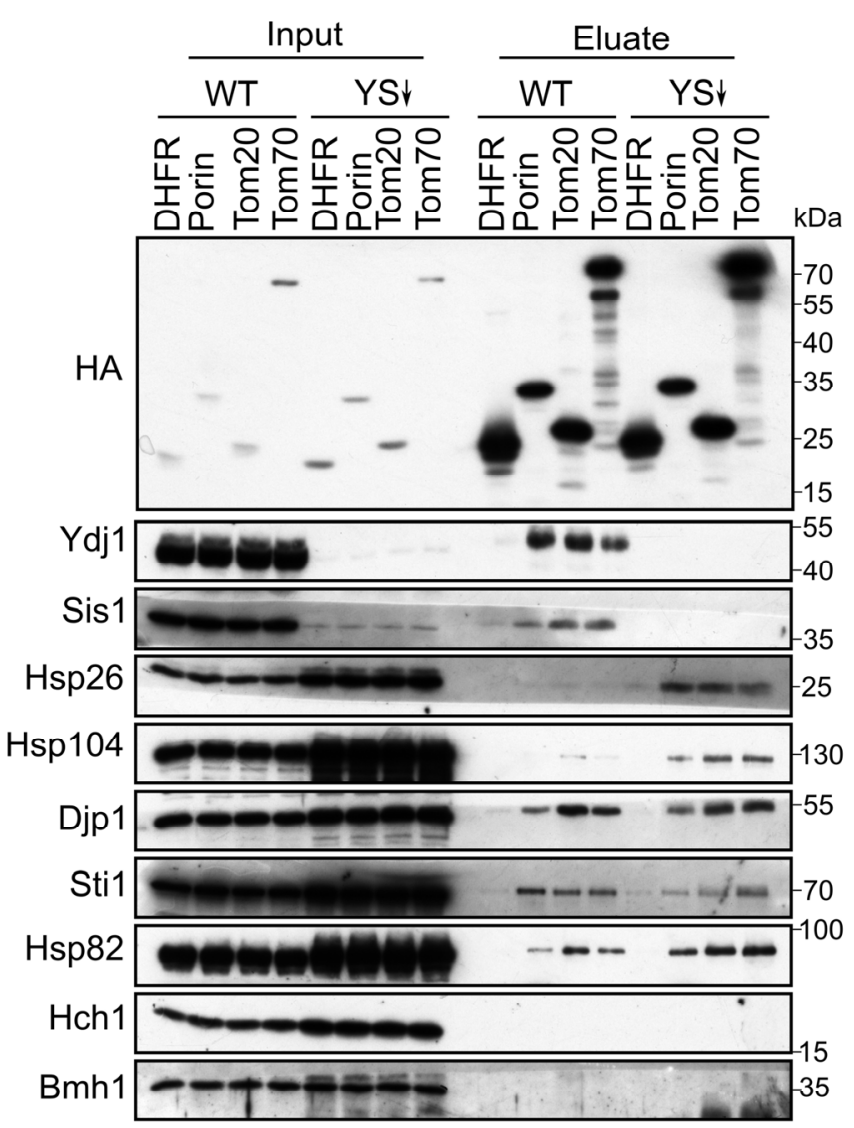


A

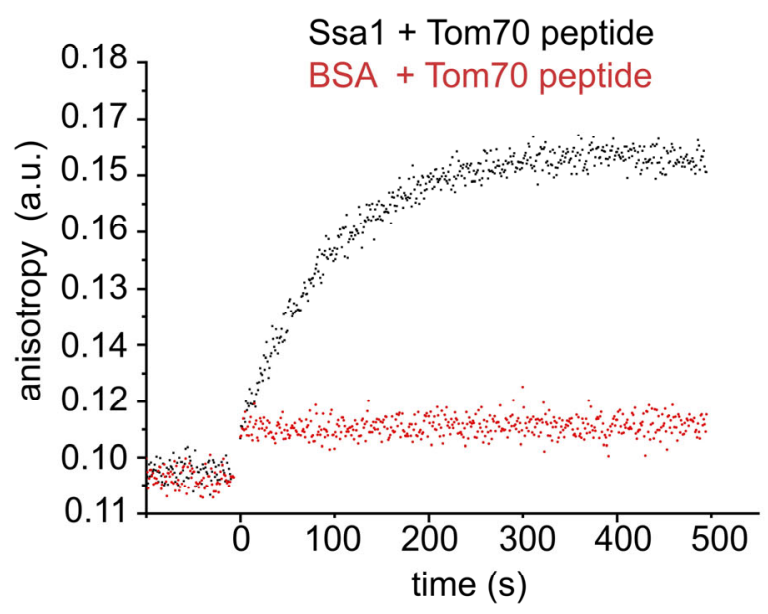

C

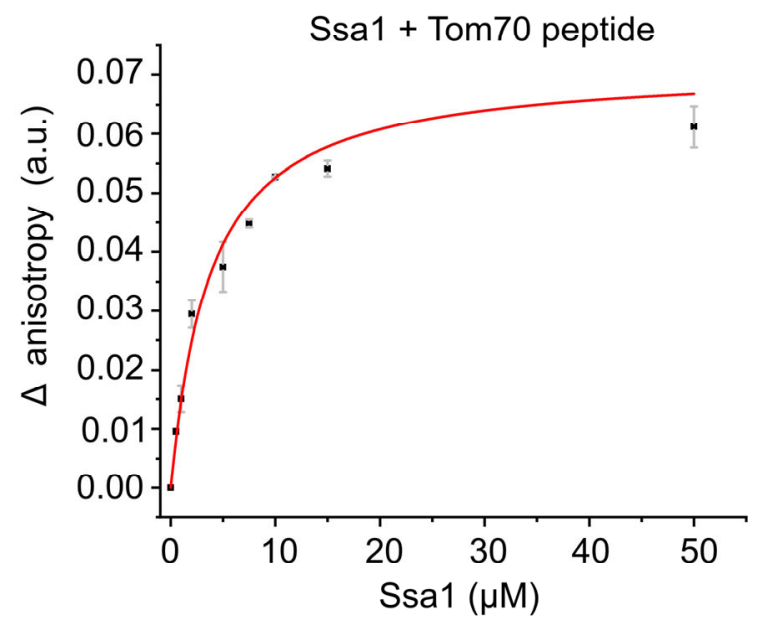

E

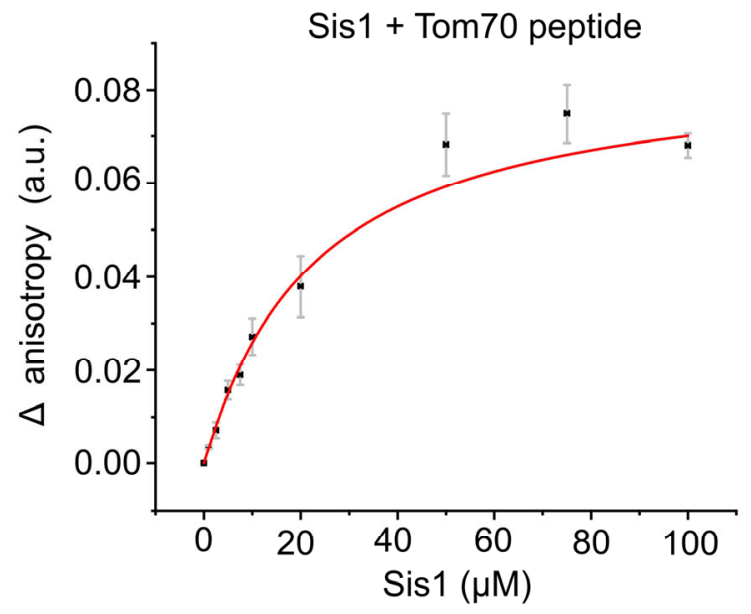

B

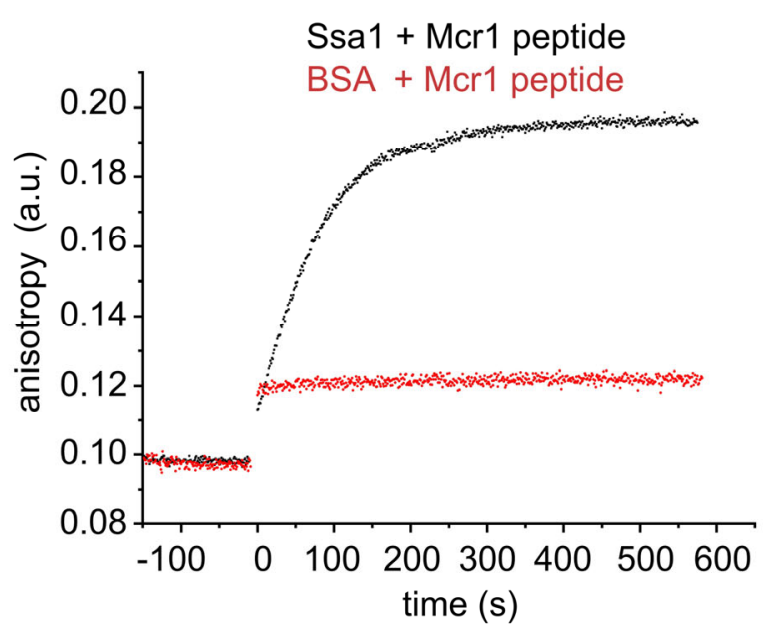

D

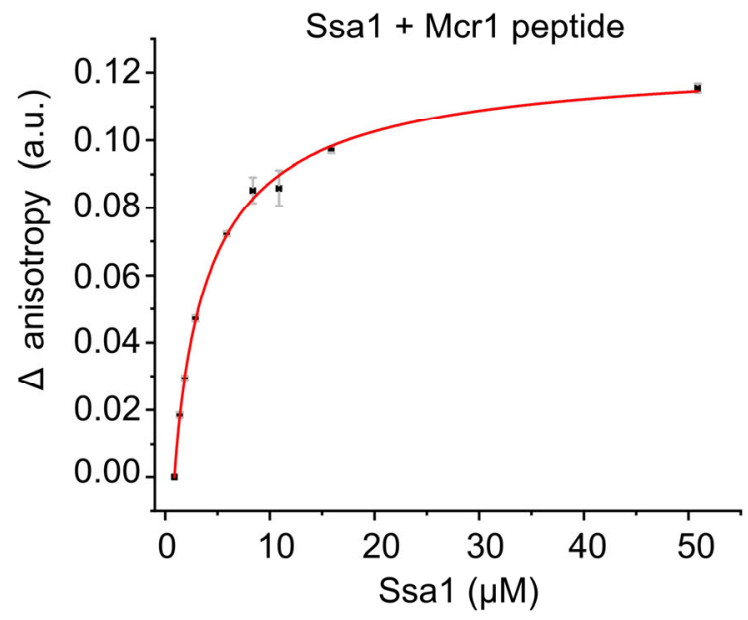

F

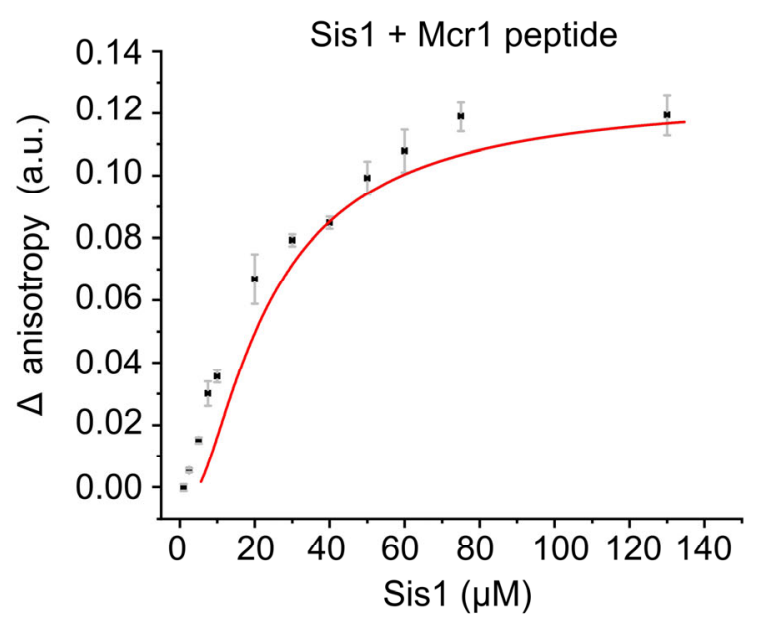


bioRxiv preprint doi: https://doi org/10 1101/2022 02 15.480587 this version posted February 17,2022. The copyright holder for this preprint (which was not certified by peer review) is the author/funder, who has granted bioRxiv a license to display the preprint in perpetuity. It is made available under aCC-BY 4.0 International license.

A

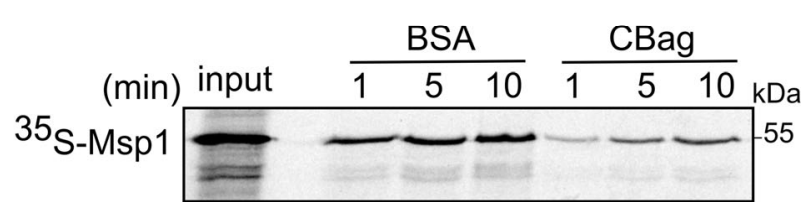

B

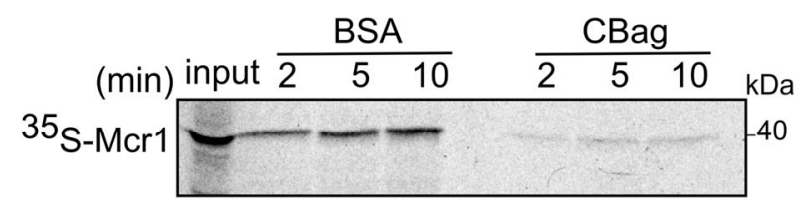

C

Mcr1-Tamra

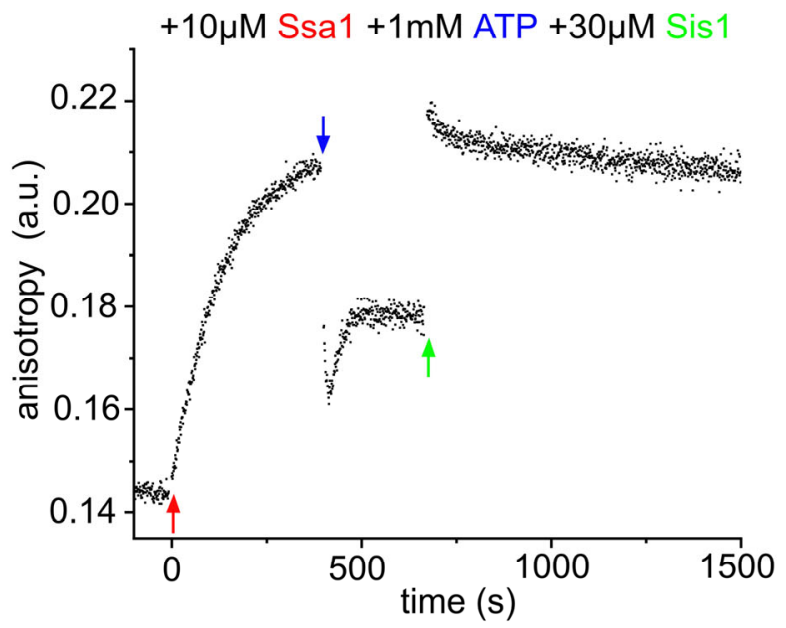

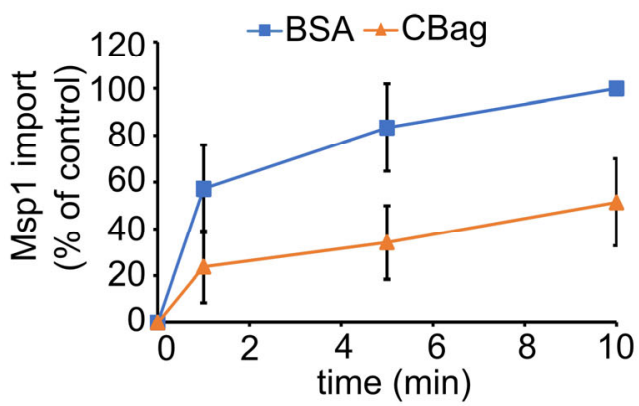

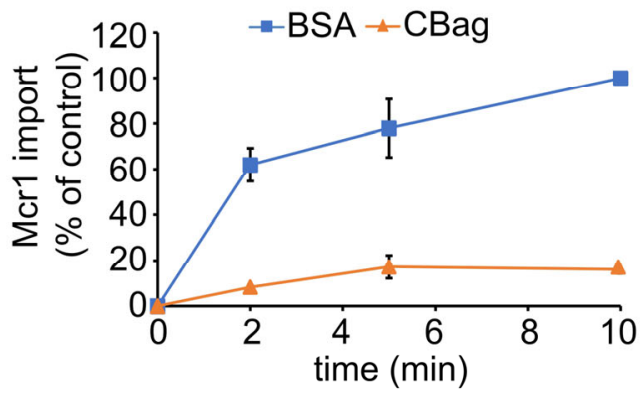

$E$

D

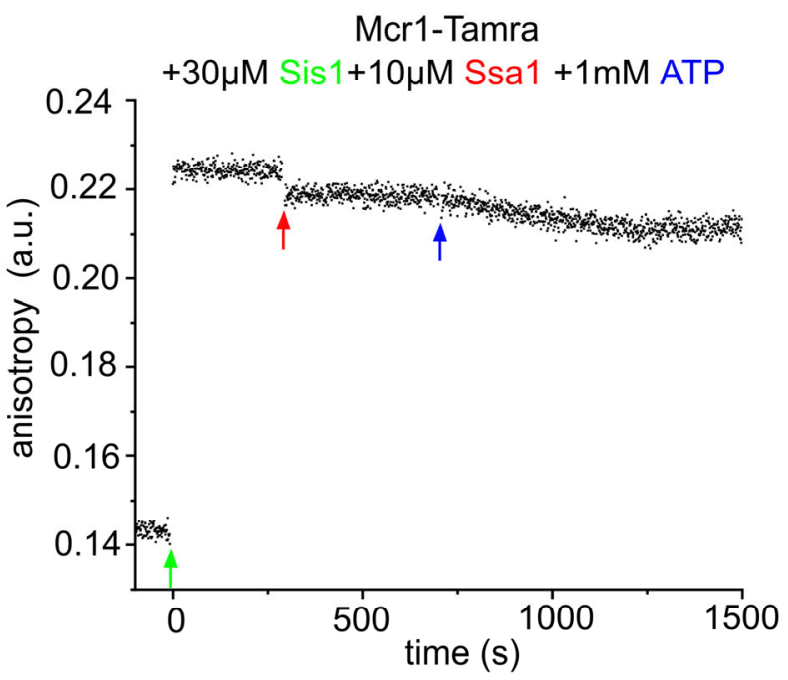

Mcr1-Tamra

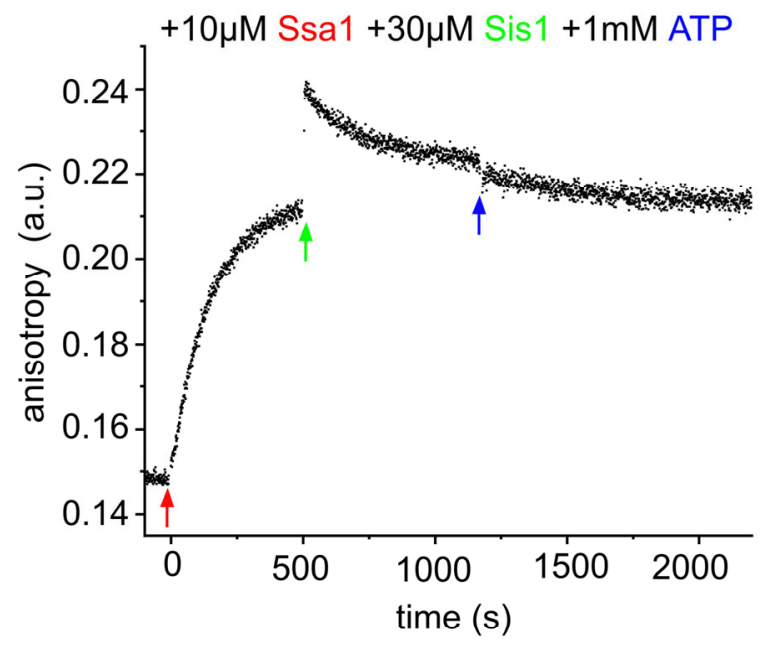


A
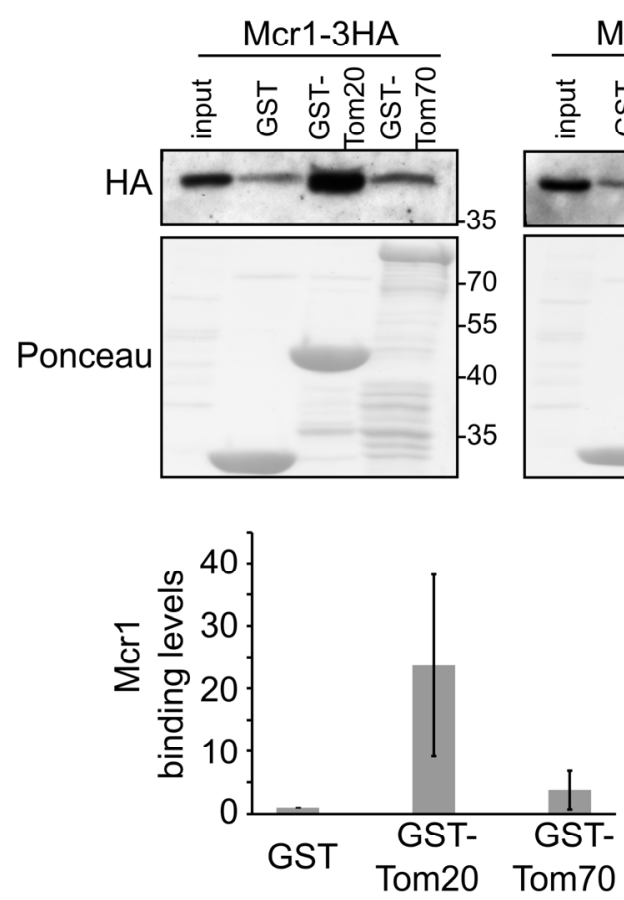

B

Mcr1-Tamra

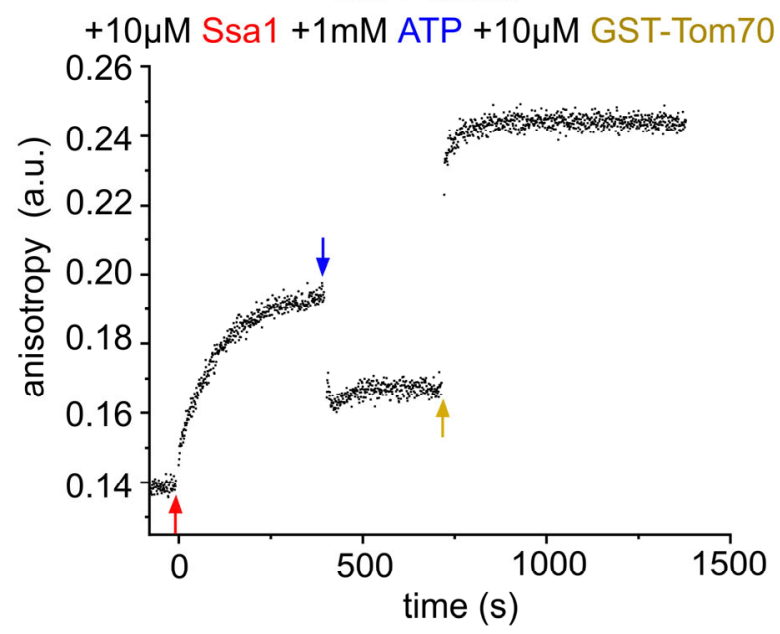

D

Mcr1-Tamra

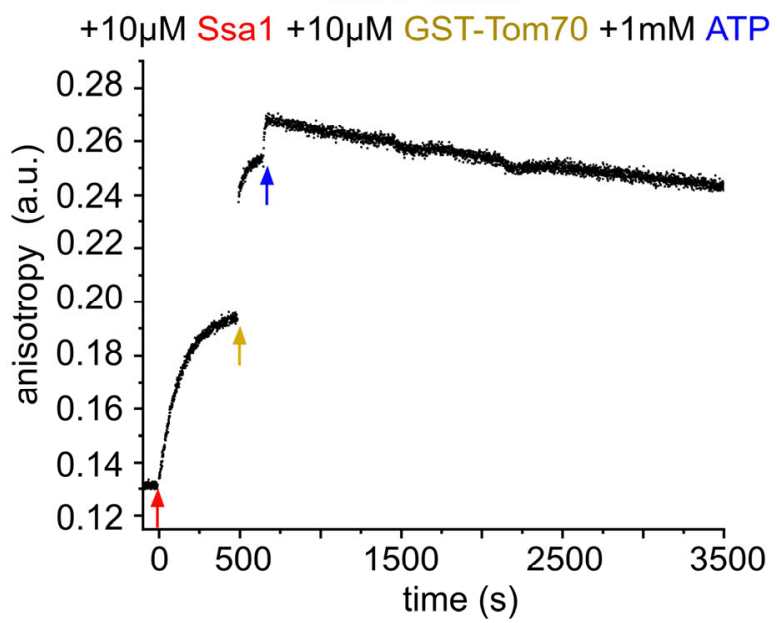

C

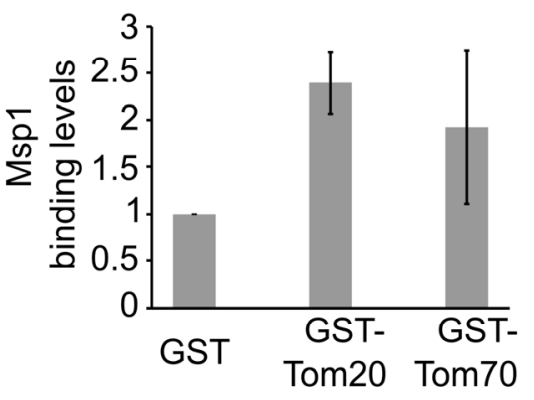

Mcr1-Tamra

$+10 \mu \mathrm{M}$ GST-Tom70 +10 $\mu \mathrm{M}$ Ssa1 +1mM ATP

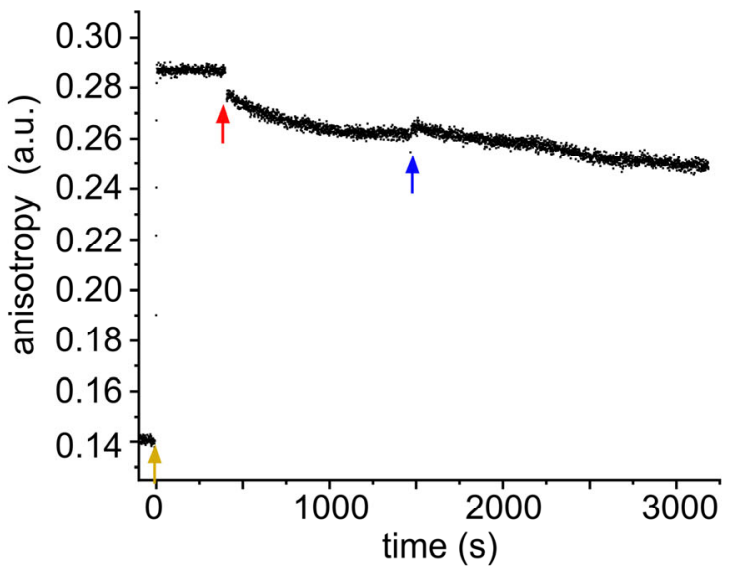

$E$

Mcr1-Tamra

$+10 \mu \mathrm{M}$ Ssa $1 / 30 \mu \mathrm{M}$ Sis $1+1 \mathrm{mM}$ ATP

$+10 \mu \mathrm{M}$ GST-Tom70

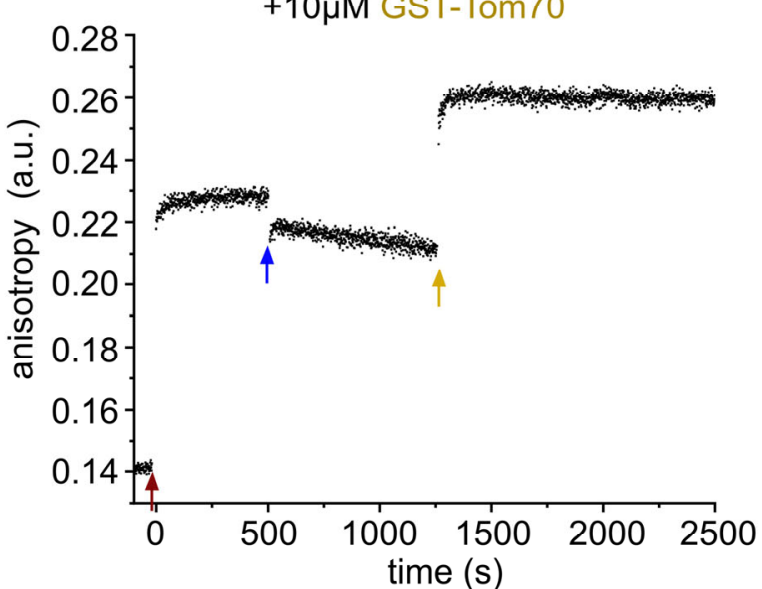


bioRxiv preprint doi: https://doi org/10.1101/2022.02 15.480587 this version posted February 17, 2022. The copyright holder for this preprint (which was not certified by peer review) is the author/funder, who has granted bioRxiv a license to display the preprint in perpetuity. It is made available under aCC-BY 4.0 International license.

A
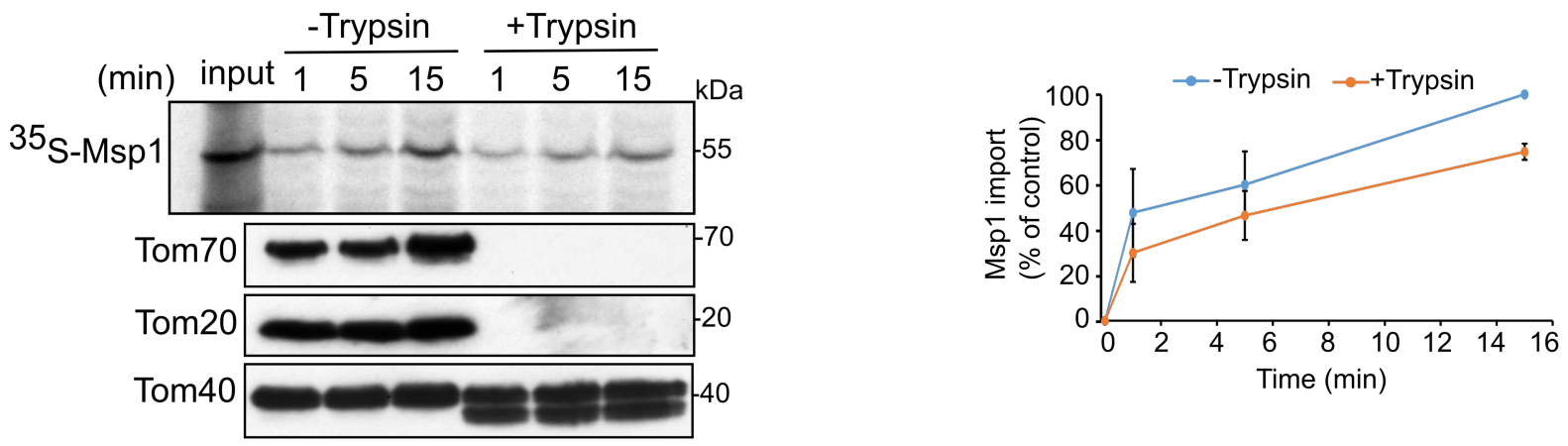

B
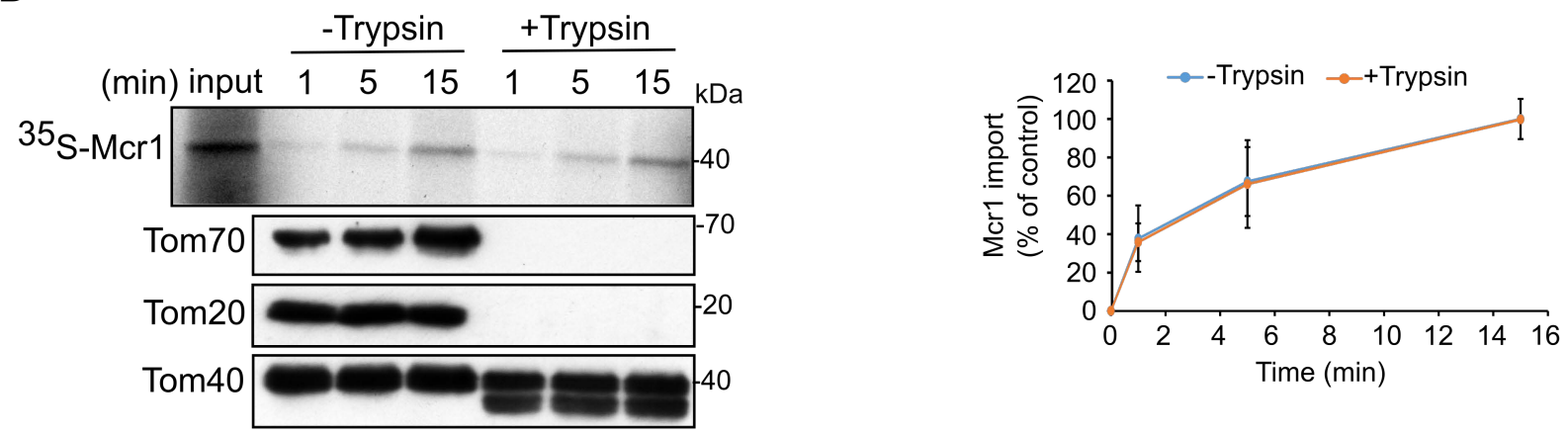

C
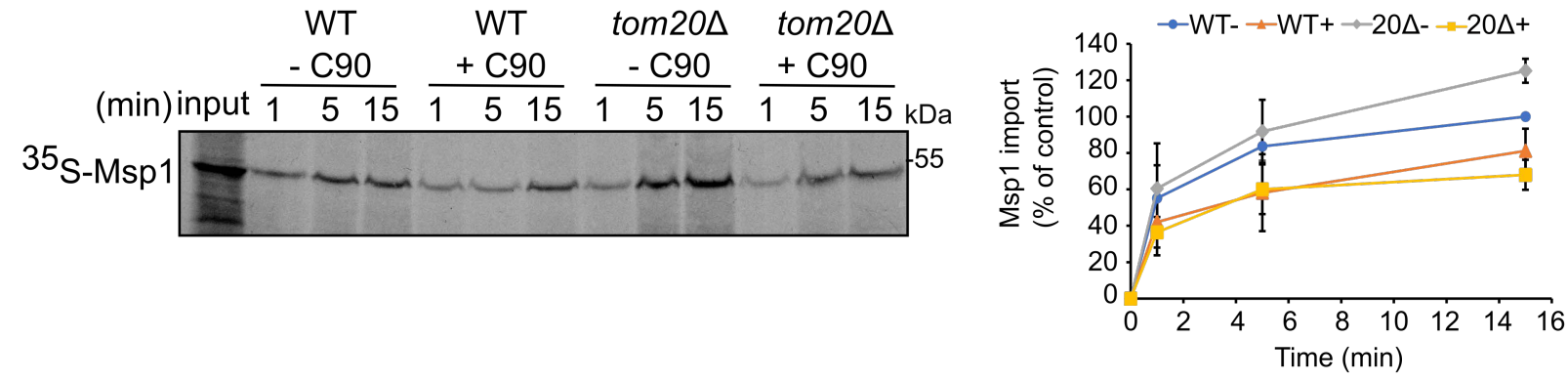

D
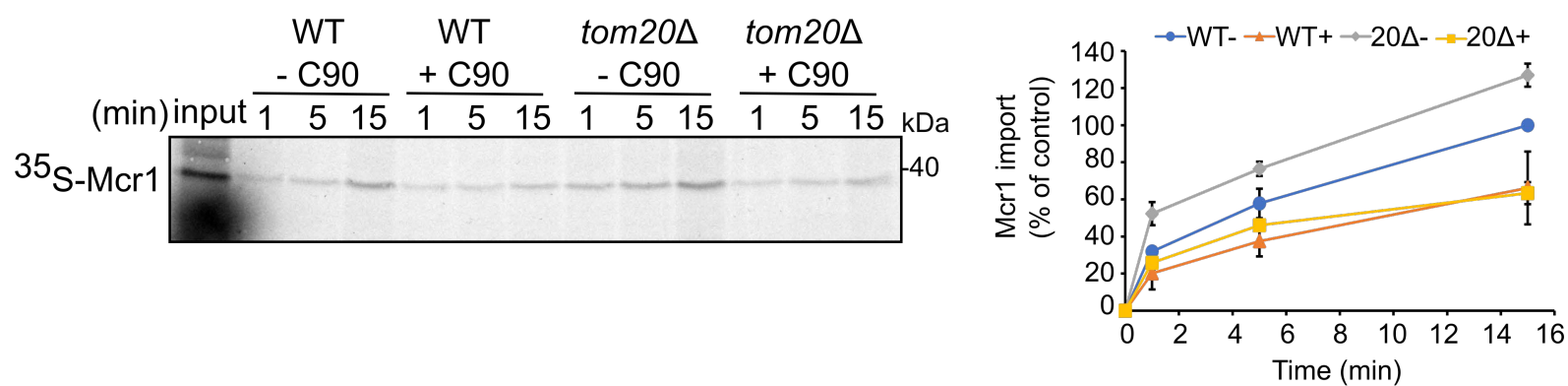

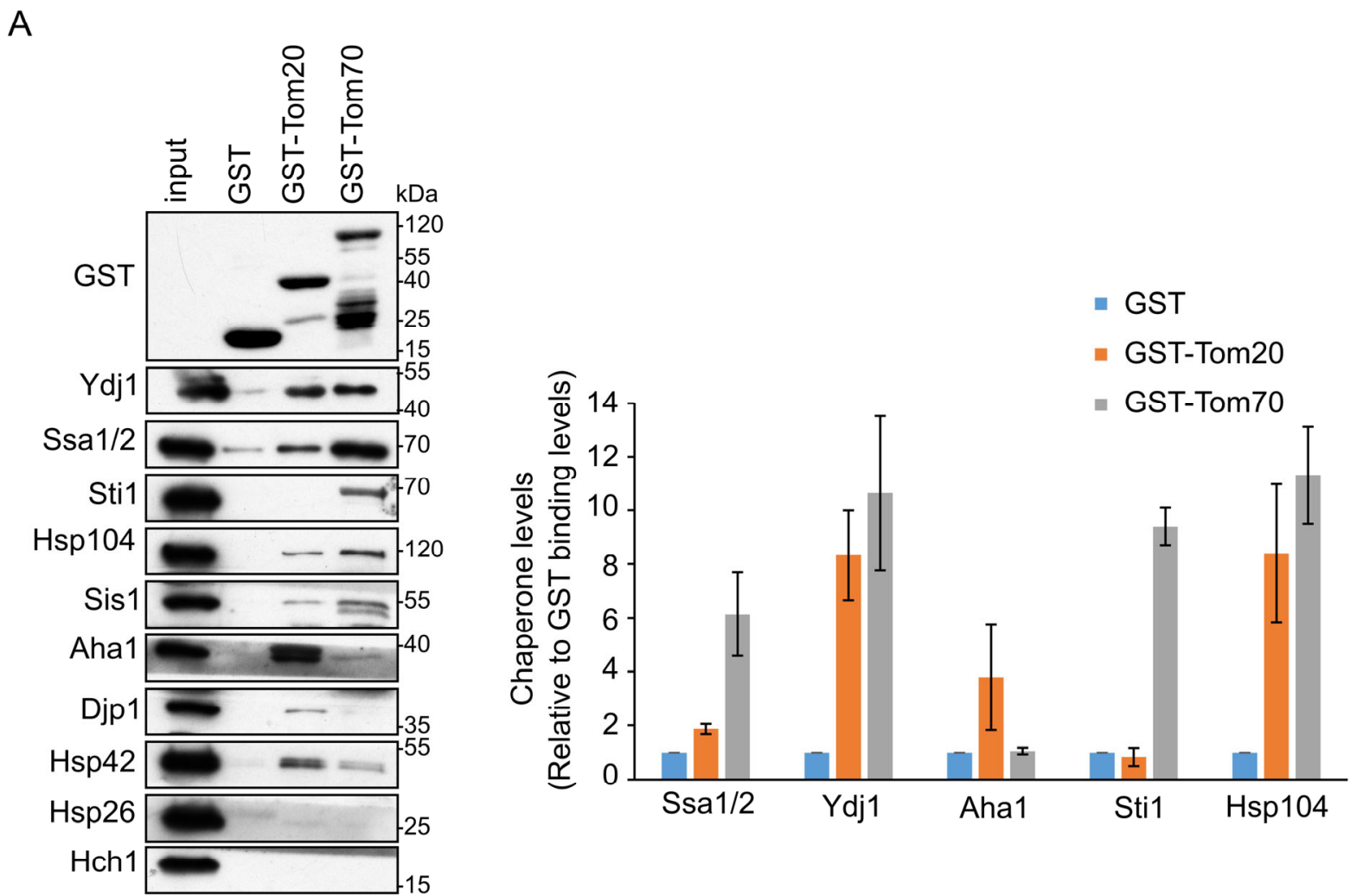

B
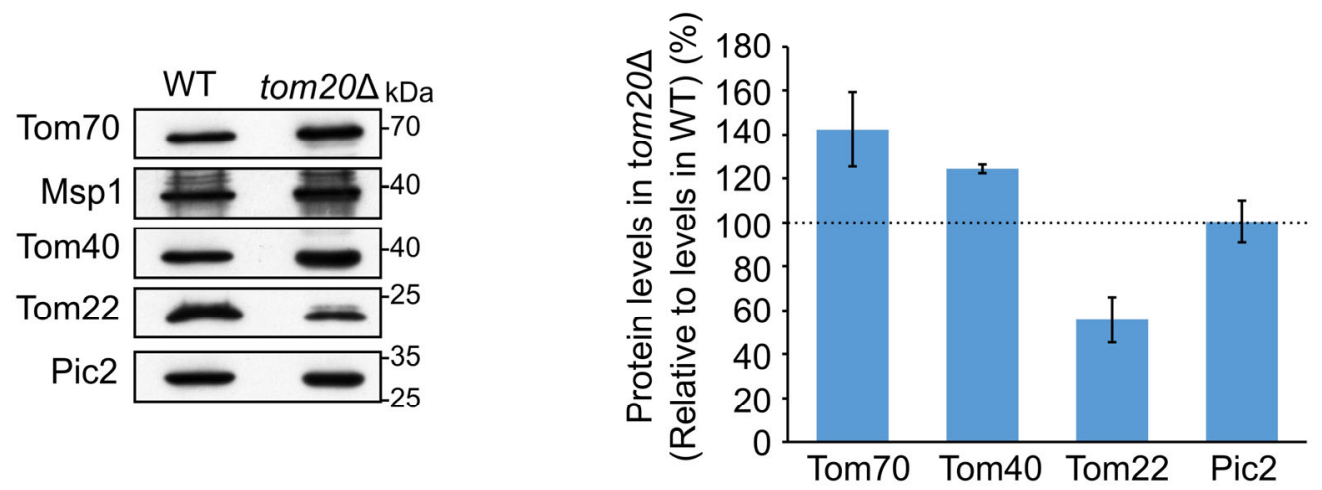

Figure S1: The cytosolic domains of the Tom receptors can associate with cytosolic (co)chaperones. (A) Left panel: Yeast extract was incubated with GST alone or with GST fused to the cytosolic domain of either Tom20 (GST-Tom20) or Tom70 (GST-Tom70). Samples of the input $(1 \%)$ and the eluate $(100 \%)$ were subjected to SDS-PAGE followed by immunodecoration with the indicated antibodies. Right panel: Bands representing the different (co)chaperones were quantified and the protein levels in the elution fraction by using GST alone was set to 1 . The results of three independent experiments are presented as mean values \pm SD of. (B) Left panel: Mitochondria isolated from either tom20 $\Delta$, or its corresponding WT strain were analyzedby SDS-PAGE and immunodecoration with antibodies against the indicated proteins. Pic2, an inner membrane protein that was used as a loading control. Right panel: Protein levels were quantified and the values of the bands corresponding to control organelles were set to $100 \%$. Results of three independent experiments are presented as mean values \pm SD 
bioRxiv preprint doi: https://doi.org/10.1101/2022.02.15.480587; this version posted February 17, 2022. The copyright holder for this preprint (which was not certified by peer review) is the author/funder, who has granted bioRxiv a license to display the preprint in perpetuity. It is made available under aCC-BY 4.0 International license.

Table S1: (co)chaperones that co-purified with in vitro translated proteins

A

\begin{tabular}{c|c|c|c|c|} 
Protein name & Gene name & Mock & $\begin{array}{c}\text { Msp1 } \\
\text { (iBAQ) }\end{array}$ & $\begin{array}{c}\text { Mcr1 } \\
\text { (iBAQ) }\end{array}$ \\
\hline Heat shock protein STI1 & STI1 & 0 & 1383200 & 6860600 \\
\hline Vacuolar transporter chaperone 4 & VTC4 & 0 & 1575800 & 3677300 \\
\hline Vacuolar transporter chaperone 2 & VTC2 & 0 & 270840 & 2372800 \\
\hline $\begin{array}{c}\text { Mitochondrial clpX-like chaperone } \\
\text { MCX1 }\end{array}$ & MCX1 & 0 & 719400 & 2178900 \\
\hline $\begin{array}{c}\text { ATP-dependent molecular chaperone } \\
\text { HSP82 }\end{array}$ & HSP82 & 0 & 180250 & 1771700 \\
\hline HSP70 co-chaperone SNL1 & SNL1 & 0 & 171400 & 1531500 \\
\hline Heat shock protein SSA4 & SSA4 & 0 & 0 & 828380 \\
\hline Heat shock protein 70 homolog LHS1 & LHS1 & 0 & 178030 & 384110 \\
\hline SEC14 cytosolic factor & SEC14 & 0 & 356900 & 0 \\
\hline
\end{tabular}

B

\begin{tabular}{c|c|c|c|c|} 
Protein name & Gene name & Mock & $\begin{array}{c}\text { Msp1 } \\
\text { (relative } \\
\text { iBAQ) }\end{array}$ & $\begin{array}{c}\text { Mcr1 } \\
\text { (relative } \\
\text { iBAQ) }\end{array}$ \\
\hline Hsp90 co-chaperone AHA1 & AHA1 & 1 & 59.2 & 70.1 \\
\hline Heat shock protein SSB2 & SSB2 & 1 & 6.6 & 17.6 \\
\hline $\begin{array}{c}\text { ATP-dependent molecular } \\
\text { chaperone HSC82 }\end{array}$ & HSC82 & 1 & 8.6 & 16.1 \\
\hline Heat shock protein SSA2 & SSA2 & 1 & 3.5 & 11.0 \\
\hline $\begin{array}{c}\text { Heat shock protein SSC1, } \\
\text { mitochondrial }\end{array}$ & SSC1 & 1 & 4.9 & 9.7 \\
\hline Heat shock protein 104 & HSP104 & 1 & 4.7 & 9.4 \\
\hline Heat shock protein SSA1 & SSA1 & 1 & 3.3 & 8.7 \\
\hline $\begin{array}{c}\text { Heat shock protein 60, } \\
\text { mitochondrial }\end{array}$ & HSP60 & 1 & 14.9 & 8.0 \\
\hline Heat shock protein homolog SSE1 & SSE1 & 1 & 3.0 & 7.6 \\
\hline Heat shock protein SSB1 & SSB1 & 1 & 1.8 & 4.7 \\
\hline $\begin{array}{c}\text { Mitochondrial protein import } \\
\text { protein MAS5 }\end{array}$ & YDJ1 & 1 & 4.0 & 2.8 \\
\hline Protein SIS1 & SIS1 & 1 & 1.4 & 2.0 \\
\hline Zuotin & ZUO1 & 1 & 1.50 & 1.87 \\
\hline
\end{tabular}

Table S1: (A) List of chaperones that were found in the elution fraction of Msp1 and Mcr1 but not in the elution of mock pull-down. The iBAQ values of the specified proteins are indicated. (B) List of chaperones that were enriched in the elution fraction of Msp1 and Mcr1 as compared to their levels in the elution from mock pull-down assay are indicated. The iBAQ value of each protein in the eluate of the mock pull-down was set to 1 and the relative values in the pull-down assays with either Msp1 or Mcr1 as compared to the value in the mock sample are indicated. 
Key Resource Tables

Table S2. Yeast strains used in this study

\begin{tabular}{|l|l|l|}
\hline Strain & Genotype & Reference \\
\hline WT & W303 $\alpha$ & Lab stock \\
\hline tetO7-Ubi-L-Ydj1 & $\begin{array}{l}\text { YMK120 } \alpha, \text { ydj1::tetO7-Ubiquitin- } \\
\text { Leu-YDJ1 KanMX4 }\end{array}$ & This Study \\
\hline tetO7-Ubi-L-Sis1 & $\begin{array}{l}\text { YMK120 } \alpha, \\
\text { sis1::tetO7-Ubiquitin-Leu-SIS1 } \\
\text { His3MX }\end{array}$ & This Study \\
\hline tetO7-Ubi-L-Ydj1/Sis1 & $\begin{array}{l}\text { YMK120 } \alpha, \text { tetO7-Ubi-Leu- } \\
\text { SIS1:HisMX3a; tetO7-Ubi-Leu- }\end{array}$ & This Study \\
& YDJ1:KanMX4 & \\
\hline Tom204 & W303 $\alpha$, tom20::HIS3 & Lab stock \\
\hline
\end{tabular}

Table S3. Primers used in this study

\begin{tabular}{|c|c|c|c|}
\hline Construct & $\begin{array}{l}\text { Primer } \\
\text { name }\end{array}$ & Sequence $5^{\prime}-3^{\prime}$ & Note \\
\hline \multirow[t]{2}{*}{ Msp1 } & LDFWD07 & 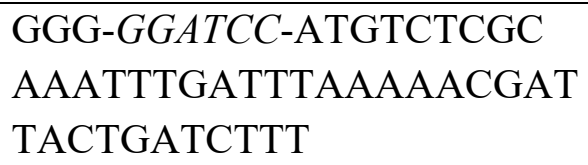 & $\begin{array}{l}\text { Amplification of } M S P 1, \\
\text { BamHI restriction site at } 5\end{array}$ \\
\hline & LDREV08 & $\begin{array}{l}\text { GGG- } A A G C T T \text {-ATCAAGAGG } \\
\text { TTGAGATGACAACGTACTTG }\end{array}$ & $\begin{array}{l}\text { Amplification of } M S P 1, \\
\text { HindIII restriction site at } 5\end{array}$ \\
\hline \multirow[t]{2}{*}{ yk Msp1 } & LDFWD09 & $\begin{array}{l}\text { GGG-GGATCC-AAAAAAATG } \\
\text { TCTCGCAAATTTGATTTAAA } \\
\text { AACGATTACTGATCTTT }\end{array}$ & $\begin{array}{l}\text { Amplification of yk- } M S P 1 \text {, } \\
\text { BamHI restriction site at 5, }\end{array}$ \\
\hline & LDREV08 & $\begin{array}{l}\text { GGG- } A A G C T T \text {-TTAATCAAGA } \\
\text { GGTTGAGATGACAAC }\end{array}$ & $\begin{array}{l}\text { Amplification of } M S P 1, \\
\text { HindIII restriction site at } 5 \text {, }\end{array}$ \\
\hline \multirow[t]{2}{*}{$\begin{array}{l}\text { yk Msp1- } \\
\text { 3HA }\end{array}$} & $\begin{array}{l}\text { LDRFWD02 } \\
8\end{array}$ & $\begin{array}{l}\text { CACAC- } G A G C T C \text {-AAAAAA- } \\
\text { ATGTCTCGCAAATTTGATTT } \\
\text { AAAAACG }\end{array}$ & $\begin{array}{l}\text { Amplification of yk- } M S P 1 \text {, } \\
\text { SacI restriction site at } 5\end{array}$ \\
\hline & \begin{tabular}{|l|} 
LDRREV029 \\
\end{tabular} & $\begin{array}{l}\text { CACAC-GGATCC-CCATCAA } \\
\text { GAGGTTGAGATGACAACGT } \\
\text { AC }\end{array}$ & $\begin{array}{l}\text { Amplification of } M S P 1, \\
\text { BamHI restriction site at } 5\end{array}$ \\
\hline $\begin{array}{l}\text { yk Mcr1- } \\
\text { 3HA }\end{array}$ & LDFWD038 & $\begin{array}{l}\text { GGG-GAATTC-AAAAAA- } \\
\text { ATGTTTTCCAGATTATCCAG } \\
\text { ATCTCACTCAAAAGC }\end{array}$ & $\begin{array}{l}\text { Amplification of yk-MCRI, } \\
\text { EcoRI restriction site at } 5,\end{array}$ \\
\hline
\end{tabular}




\begin{tabular}{|c|c|c|c|}
\hline & LDREV039 & 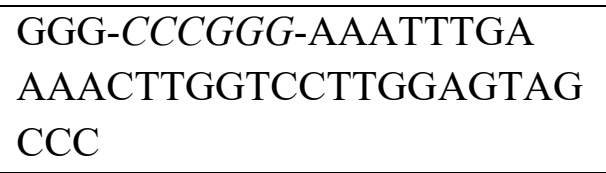 & $\begin{array}{l}\text { Amplification of } M C R 1, \\
\text { SmaI restriction site at } 5\end{array}$ \\
\hline \multirow[t]{2}{*}{$\begin{array}{l}\text { yk Tom20- } \\
\text { 3HA }\end{array}$} & LDFWD0102 & $\begin{array}{l}\text { GGG-GGTACC-AAAAAA- } \\
\text { ATGTCCCAGTCGAACCCTAT } \\
\text { CTTAC }\end{array}$ & $\begin{array}{l}\text { Amplification of yk- } \\
\text { TOM20, KpnI restriction } \\
\text { site at 5, }\end{array}$ \\
\hline & LDREV0103 & $\begin{array}{l}\text { GGG-GGATCC-GG- } \\
\text { GTCATCGATATCGTTAGCTT } \\
\text { CAGC }\end{array}$ & $\begin{array}{l}\text { Amplification of TOM20, } \\
\text { BamHI restriction site at } 5 \text {, }\end{array}$ \\
\hline \multirow[t]{2}{*}{$\begin{array}{l}\text { yk Tom70- } \\
\text { 3HA }\end{array}$} & LDFWD0106 & $\begin{array}{l}\text { GGG-GGTACC-AAAAAA- } \\
\text { ATGAAGAGCTTCATTACAAG } \\
\text { GAACAAGAC }\end{array}$ & $\begin{array}{l}\text { Amplification of yk- } \\
T O M 70, \mathrm{KpnI} \text { restriction } \\
\text { site at 5, }\end{array}$ \\
\hline & LDREV0107 & $\begin{array}{l}\text { GGG-GGATCC-GGCATTAAAC } \\
\text { CCTGTTCGCGTAATTTAGC }\end{array}$ & $\begin{array}{l}\text { Amplification of TOM70, } \\
\text { BamHI restriction site at } 5 \text {, }\end{array}$ \\
\hline \multirow[t]{2}{*}{$\begin{array}{l}\text { yk Msp1- } \\
\text { TMD-3HA }\end{array}$} & LDFWD040 & $\begin{array}{l}\text { GGG-GAATTC-AAAAAA- } \\
\text { ATGTCTCGCAAATTTGATTT } \\
\text { AAAAACG }\end{array}$ & $\begin{array}{l}\text { Amplification of yk-TMD } \\
(1-32) \text { of } M S P 1, \text { EcoRI } \\
\text { restriction site at } 5\end{array}$ \\
\hline & LDREV041 & $\begin{array}{l}\text { GGG-GGATCC-CCGTTGAGT } \\
\text { AGCCGACTGACCA }\end{array}$ & $\begin{array}{l}\text { Amplification of TMD (1- } \\
\text { 32) of } M S P 1, \text { BamHI } \\
\text { restriction site at 5, }\end{array}$ \\
\hline \multirow[t]{2}{*}{$\begin{array}{l}\text { yk Msp1- } \\
\text { CD--3HA }\end{array}$} & $\begin{array}{l}\text { LDRFWD05 } \\
2\end{array}$ & $\begin{array}{l}\text { CACAC-GAGCTC-AAAAAA- } \\
\text { ATGGATGTTGAATCAGGACC } \\
\text { GTTATCAGG }\end{array}$ & $\begin{array}{l}\text { Amplification of yk-CD } \\
(33-363) \text { of } M S P 1, \mathrm{SacI} \\
\text { restriction site at } 5,\end{array}$ \\
\hline & LDREV053 & $\begin{array}{l}\text { CACAC-GGATCC-CCATCA } \\
\text { AGAGGTTGAGATGACAACG } \\
\text { TACTTGTAGC }\end{array}$ & $\begin{array}{l}\text { Amplification of } \mathrm{CD}(33- \\
\text { 363) of } M S P 1, \text { BamHI } \\
\text { restriction site at } 5\end{array}$ \\
\hline \multirow[t]{2}{*}{$\begin{array}{l}\text { yk Mcr1- } \\
\text { TMD-3HA }\end{array}$} & LDFWD060 & $\begin{array}{l}\text { CACAC-GAATTC-AAAAAA- } \\
\text { ATGTTTTCCAGATTATCCAG } \\
\text { ATCTC }\end{array}$ & $\begin{array}{l}\text { Amplification of yk-TMD } \\
(1-39) \text { of } M C R 1, \text { EcoRI } \\
\text { restriction site at } 5\end{array}$ \\
\hline & LDREV061 & $\begin{array}{l}\text { CACAC- } C C C G G G \text {-GAC AAA } \\
\text { GGA ATG TTG GTT ACG GTT } \\
\mathrm{T}\end{array}$ & $\begin{array}{l}\text { Amplification of TMD (1- } \\
\text { 39) of } M C R 1, \mathrm{XmaI} \\
\text { restriction site at } 5\end{array}$ \\
\hline \multirow[t]{2}{*}{$\begin{array}{l}\text { yk Mcr1- } \\
\text { CD-3HA }\end{array}$} & $\begin{array}{l}\text { LDRFWD05 } \\
4\end{array}$ & $\begin{array}{l}\text { CACAC-GAATTC-AAAAAA- } \\
\text { ATGCATTCCTTTGTCTTCAA } \\
\text { TGAATC }\end{array}$ & $\begin{array}{l}\text { Amplification of yk-CD } \\
(35-302) \text { of } M C R 1, \text { EcoRI } \\
\text { restriction site at } 5\end{array}$ \\
\hline & LDREV055 & $\begin{array}{l}\text { CACAC- } C C C G G G \text {-AAATTTGA } \\
\text { AAACTTGGTCCTTGGAGTAG }\end{array}$ & $\begin{array}{l}\text { Amplification of CD (35- } \\
\text { 302) of } M C R 1, \mathrm{XmaI} \\
\text { restriction site at } 5\end{array}$ \\
\hline
\end{tabular}




\begin{tabular}{|c|c|c|c|}
\hline $\begin{array}{l}\text { yk Tom20- } \\
\text { TMD-3HA }\end{array}$ & LDFWD0102 & $\begin{array}{l}\text { GGG-GGTACC-AAAAAA- } \\
\text { ATGTCCCAGTCGAACCCTAT } \\
\text { CTTAC }\end{array}$ & $\begin{array}{l}\text { Amplification of yk-TMD } \\
(1-30) \text { of TOM } 20, \mathrm{KpnI} \\
\text { restriction site at } 5\end{array}$ \\
\hline & LDREV0113 & $\begin{array}{l}\text { GGG-GGATCC-GGGTCAAAG } \\
\text { TAGATAGCATAACCGGTG }\end{array}$ & $\begin{array}{l}\text { Amplification of TMD (1- } \\
30) \text { of TOM20, BamHI } \\
\text { restriction site at } 5 \text {, }\end{array}$ \\
\hline \multirow[t]{2}{*}{$\begin{array}{l}\text { yk Tom20- } \\
\text { CD-3HA }\end{array}$} & LDFWD0112 & $\begin{array}{l}\text { GGG-GGTACC-AAAAAA- } \\
\text { ATGAGAAATAGCCCGCAAT } \\
\text { TCAGGAA }\end{array}$ & $\begin{array}{l}\text { Amplification of yk-CD } \\
(33-183) \text { of TOM20, KpnI } \\
\text { restriction site at } 5\end{array}$ \\
\hline & LDREV0103 & $\begin{array}{l}\text { GGG-GGATCC-GGGTCATCGA } \\
\text { TATCGTTAGCTTCAGC }\end{array}$ & $\begin{array}{l}\text { Amplification of CD (33- } \\
\text { 183) of TOM20, BamHI } \\
\text { restriction site at } 5\end{array}$ \\
\hline \multirow[t]{2}{*}{$\begin{array}{l}\text { yk Tom70- } \\
\text { TMD-3HA }\end{array}$} & LDFWD0106 & $\begin{array}{l}\text { GGG-GGTACC-AAAAAA- } \\
\text { ATGAAGAGCTTCATTACAAG } \\
\text { GAACAAGAC }\end{array}$ & $\begin{array}{l}\text { Amplification of yk-TMD } \\
(1-32) \text { of TOM70, KpnI } \\
\text { restriction site at } 5\end{array}$ \\
\hline & LDREV0111 & $\begin{array}{l}\text { GGG-GGATCC-GGCAATTGGT } \\
\text { TGTAATAATAGTAGGCACC }\end{array}$ & $\begin{array}{l}\text { Amplification of TMD (1- } \\
\text { 32) of TOM70, BamHI } \\
\text { restriction site at } 5 \text {, }\end{array}$ \\
\hline \multirow[t]{2}{*}{$\begin{array}{l}\text { yk Tom70- } \\
\text { CD-3HA }\end{array}$} & LDFWD0110 & $\begin{array}{l}\text { GGG-GGTACC-AAAAAA- } \\
\text { ATGCAACAACAACAACGAG } \\
\text { GAAAAAAGAACAC }\end{array}$ & $\begin{array}{l}\text { Amplification of yk-CD } \\
(33-617) \text { of } T O M 70, \mathrm{KpnI} \\
\text { restriction site at } 5\end{array}$ \\
\hline & LDREV0107 & $\begin{array}{l}\text { GGG-GGATCC-GGCATTAAAC } \\
\text { CCTGTTCGCGTAATTTAGC }\end{array}$ & $\begin{array}{l}\text { Amplification of CD ( } 33- \\
617) \text { of } T O M 70, \mathrm{BamHI} \\
\text { restriction site at } 5\end{array}$ \\
\hline \multirow[t]{2}{*}{$\begin{array}{l}\text { tetO7-Ubi- } \\
\text { L-Ydj1 }\end{array}$} & TJ192 & $\begin{array}{l}\text { CATATCTTTTGATAGAACAT } \\
\text { AATTAAAAATTATCCAAACT } \\
\text { GAATTCTACACAGTATAGCG } \\
\text { ACCAGCATTCACATACG }\end{array}$ & $\begin{array}{l}\text { Amplification of a cassette } \\
\text { containing tet } \mathrm{O}_{7} \text { promotor- } \\
\text { Ubiquitin-Leu, to } \\
\text { genomically fuse to } Y D J 1\end{array}$ \\
\hline & TJ193 & $\begin{array}{l}\text { GTGGCAGTTACTGGAACACC } \\
\text { TAGAATATCGTAAAACTTAG } \\
\text { TTTCTTTAACCAAACCACCT } \\
\text { CTCAATCTCAAGACCAAG }\end{array}$ & $\begin{array}{l}\text { Amplification of a cassette } \\
\text { containing tetO } 7 \text { promotor- } \\
\text { Ubiquitin-Leu, to } \\
\text { genomically fuse to } Y D J 1\end{array}$ \\
\hline \multirow[t]{2}{*}{$\begin{array}{l}\text { tetO } 7 \text {-Ubi- } \\
\text { L-Sis1 }\end{array}$} & TJ196 & $\begin{array}{l}\text { GGATAAGTTGTTTGCATTTT } \\
\text { AAGATTTTTTTTTTAATACA } \\
\text { TTCACATCAACAGTATAGCG } \\
\text { ACCAGCATTCACATACG }\end{array}$ & $\begin{array}{l}\text { Amplification of a cassette } \\
\text { containing tetO } 7 \text { promotor- } \\
\text { Ubiquitin-Leu, to } \\
\text { genomically fuse to SIS1 }\end{array}$ \\
\hline & TJ197 & $\begin{array}{l}\text { TTAGCACTTGGAGATACTCC } \\
\text { AAGTAAATCATAAAGTTTTG } \\
\text { TCTCCTTGACCAAACCACCT } \\
\text { CTCAATCTCAAGACCAAG }\end{array}$ & $\begin{array}{l}\text { Amplification of a cassette } \\
\text { containing tetO } \mathrm{O}_{7} \text { promotor- } \\
\text { Ubiquitin-Leu, to } \\
\text { genomically fuse to SIS1 }\end{array}$ \\
\hline
\end{tabular}


Table S4: Plasmids used in this study

\begin{tabular}{|c|c|c|c|}
\hline Plasmid & Insert & Marker & Reference \\
\hline pGEM4polyA-3HA & C-terminal $3 \times$ HA-tag & $A m p^{R}$ & Jores et al. 2018 \\
\hline $\begin{array}{l}\text { pGEM4polyA-yk-DHFR- } \\
\text { 3HA }\end{array}$ & $\begin{array}{l}\text { Yeast kozak sequence } \\
\text { (AAAAAAATG) DHFR-3 } \times \text { HA- } \\
\text { tag }\end{array}$ & $A m p^{R}$ & Jores et al. 2018 \\
\hline $\begin{array}{l}\text { pGEM4polyA-yk-Porin- } \\
\text { 3HA }\end{array}$ & $\begin{array}{l}\text { Yeast kozak sequence } \\
\text { (AAAAAAATG) Porin-3 } \times \text { HA- } \\
\text { tag }\end{array}$ & $A m p^{R}$ & Jores at al. 2018 \\
\hline $\begin{array}{l}\text { pGEM4polyA-yk-Fis1- } \\
\text { 3HA }\end{array}$ & $\begin{array}{l}\text { Yeast kozak sequence } \\
\text { (AAAAAAATG) Fis1-3 } \times \text { HA- } \\
\text { tag }\end{array}$ & $A m p^{R}$ & \\
\hline $\begin{array}{l}\text { pGEM4polyA-yk-Msp1- } \\
\text { 3HA }\end{array}$ & $\begin{array}{l}\text { Yeast kozak sequence } \\
\text { (AAAAAAATG) Msp1-3 } \times \text { HA- } \\
\text { tag }\end{array}$ & $A m p^{R}$ & This study \\
\hline $\begin{array}{l}\text { pGEM4polyA-yk-Mcr1- } \\
\text { 3HA }\end{array}$ & $\begin{array}{l}\text { Yeast kozak sequence } \\
\text { (AAAAAAATG) Mcr1-3 × HA- } \\
\text { tag }\end{array}$ & $A m p^{R}$ & This study \\
\hline $\begin{array}{l}\text { pGEM4polyA-yk-Tom20- } \\
\text { 3HA }\end{array}$ & $\begin{array}{l}\text { Yeast kozak sequence } \\
\text { (AAAAAAATG) Tom20-3× } \\
\text { HA-tag }\end{array}$ & $A m p^{R}$ & This study \\
\hline $\begin{array}{l}\text { pGEM4polyA-yk-Tom70- } \\
\text { 3HA }\end{array}$ & $\begin{array}{l}\text { Yeast kozak sequence } \\
\text { (AAAAAAATG) Tom70-3 } \times \\
\text { HA-tag }\end{array}$ & $A m p^{R}$ & This study \\
\hline $\begin{array}{l}\text { pGEM4polyA-yk- } \\
\text { Msp1(33-363)-3HA }\end{array}$ & $\begin{array}{l}\text { Yeast kozak sequence } \\
\text { (AAAAAAATG) Msp1(1-363)-3 } \\
\times \text { HA-tag }\end{array}$ & $A m p^{R}$ & This study \\
\hline $\begin{array}{l}\text { pGEM4polyA-yk-Msp1(1- } \\
\text { 32)-3HA }\end{array}$ & $\begin{array}{l}\text { Yeast kozak sequence } \\
\text { (AAAAAAATG) Msp1(1-32)-3 } \\
\text { HA-tag }\end{array}$ & $A m p^{R}$ & This study \\
\hline $\begin{array}{l}\text { pGEM4polyA-yk- } \\
\text { Mcr1(35-302)-3HA }\end{array}$ & $\begin{array}{l}\text { Yeast kozak sequence } \\
\text { (AAAAAAATG) Mcr1(35-302)- } \\
3 \times \text { HA-tag }\end{array}$ & $A m p^{R}$ & This study \\
\hline $\begin{array}{l}\text { pGEM4polyA-yk-Mcr1(1- } \\
\text { 39)-3HA }\end{array}$ & $\begin{array}{l}\text { Yeast kozak sequence } \\
\text { (AAAAAAATG) Mcr1(1-39)-3 × } \\
\text { HA-tag }\end{array}$ & $A m p^{R}$ & This study \\
\hline $\begin{array}{l}\text { pGEM4polyA-yk- } \\
\text { Tom20(33-183)-3HA }\end{array}$ & $\begin{array}{l}\text { Yeast kozak sequence } \\
\text { (AAAAAAATG) Tom20(33- } \\
\text { 183)-3 × HA-tag }\end{array}$ & $A m p^{R}$ & This study \\
\hline
\end{tabular}




\begin{tabular}{|c|c|c|c|}
\hline $\begin{array}{l}\text { pGEM4polyA-yk- } \\
\text { Tom20(1-30)-3HA }\end{array}$ & $\begin{array}{l}\text { Yeast kozak sequence } \\
\text { (AAAAAAATG) Tom20(1-30)- } \\
3 \times \text { HA-tag }\end{array}$ & $A m p^{R}$ & This study \\
\hline $\begin{array}{l}\text { pGEM4polyA-yk- } \\
\text { Tom70(33-617)-3HA }\end{array}$ & $\begin{array}{l}\text { Yeast kozak sequence } \\
\text { (AAAAAAATG) Tom70(33- } \\
617)-3 \times \text { HA-tag }\end{array}$ & $A m p^{R}$ & This study \\
\hline $\begin{array}{l}\text { pGEM4polyA-yk- } \\
\text { Tom70(1-32)-3HA }\end{array}$ & $\begin{array}{l}\text { Yeast kozak sequence } \\
\text { (AAAAAAATG) Tom70(1-32)-3 } \\
\times \text { HA-tag }\end{array}$ & $A m p^{R}$ & This study \\
\hline pMK632His & $\begin{array}{l}\text { HIS3MX cassette tetO7-CYC1 } \\
\text { promoter-Ubiquitin-Leucin-HA- } \\
\text { tag }\end{array}$ & $A m p^{R}$ & Jores et al. 2018 \\
\hline pMK632Kan & $\begin{array}{l}\text { KanMX cassette tetO7-CYC1 } \\
\text { promoter-Ubiquitin-Leucin-HA- } \\
\text { tag }\end{array}$ & $A m p^{R}$ & Jores et al. 2018 \\
\hline pGEX4T1-GST & GST & $A m p^{R}$ & \\
\hline $\begin{array}{l}\text { pGEX4T1-GST- } \\
\text { Tom20(35-183) }\end{array}$ & Tom20(35-183) & $A m p^{R}$ & \\
\hline $\begin{array}{l}\text { pGEX4T1-GST- } \\
\text { Tom70(46-617) }\end{array}$ & Tom70(46-617) & $A m p^{R}$ & \\
\hline pPROEX-HTa-cBag & $\begin{array}{l}\text { His6-tag-TEV-human Bag- } \\
\text { 1M(151-263) }\end{array}$ & $A m p^{R}$ & Young et al. 2003 \\
\hline pPROEX-HTa-(C90) & $\begin{array}{l}\text { His6-tag-TEV-human } \\
\text { Hsp90a(566-732) }\end{array}$ & $A m p^{R}$ & Young et al. 2003 \\
\hline
\end{tabular}


Table S5. Antibodies used in this study

\begin{tabular}{|l|l|l|l|}
\hline Antibody raised against & Species & Dilution & Source \\
\hline Ssa1/2 & Rabbit & $1: 20000$ & Lab stocks \\
\hline Ydj1 & Rabbit & $1: 10000$ & Lab stocks \\
\hline Sis1 & Rabbit & $1: 20000$ & Lab stocks \\
\hline Hsp26 & Rabbit & $1: 4000$ & Lab stocks \\
\hline Hsp104 & Rabbit & $1: 25000$ & Lab stocks \\
\hline Hsp42 & Rabbit & $1: 4000$ & Lab stocks \\
\hline Hsp82 & Rabbit & $1: 20000$ & Lab stocks \\
\hline Hch1 & Rabbit & $1: 4000$ & Lab stocks \\
\hline Bmh1 & Rabbit & $1: 1000$ & Lab stocks \\
\hline Djp1 & Rabbit & $1: 2000$ & Lab of Ineke Braakman \\
\hline Sti1 & Rabbit & $1: 10000$ & Lab stocks \\
\hline Aha1 & Rabbit & $1: 2000$ & Lab stocks \\
\hline Msp1 & Rabbit & $1: 2000$ & Lab of Toshiya Endo \\
\hline Mcr1 & Rabbit & $1: 2000$ & Lab stocks \\
\hline Fis1 & Rabbit & $1: 1000$ & Lab stocks \\
\hline Tom20 & Rabbit & $1: 4000$ & Lab stocks \\
\hline Tom70 & Rabbit & $1: 5000$ & Lab stocks \\
\hline Porin & Rabbit & $1: 6000$ & Lab stocks \\
\hline Pic2 & Rabbit & $1: 2000$ & Lab stocks \\
\hline HA & Rat & $1: 1000$ & 11867423001, Roche \\
\hline Rabbit IgG HRP conjugate & Goat & $1: 10000$ & 1721019, Bio-Rad \\
\hline Rat IgG HRP conjugate & Goat & $1: 2000$ & ab6845, Abcam \\
\hline
\end{tabular}

